\title{
Theft under Stalin: A Property Rights Analysis
}

DOI:

10.1111/ehr.12121

10.1111/ehr.12121

Link to publication record in Manchester Research Explorer

\section{Citation for published version (APA):}

Gorlizki, Y. (2016). Theft under Stalin: A Property Rights Analysis. The Economic History Review, 69(1), 288-313. [12121]. https://doi.org/10.1111/ehr.12121, https://doi.org/10.1111/ehr.12121

\section{Published in:}

The Economic History Review

\section{Citing this paper}

Please note that where the full-text provided on Manchester Research Explorer is the Author Accepted Manuscript or Proof version this may differ from the final Published version. If citing, it is advised that you check and use the publisher's definitive version.

\section{General rights}

Copyright and moral rights for the publications made accessible in the Research Explorer are retained by the authors and/or other copyright owners and it is a condition of accessing publications that users recognise and abide by the legal requirements associated with these rights.

\section{Takedown policy}

If you believe that this document breaches copyright please refer to the University of Manchester's Takedown Procedures [http://man.ac.uk/04Y6Bo] or contact uml.scholarlycommunications@manchester.ac.uk providing relevant details, so we can investigate your claim.

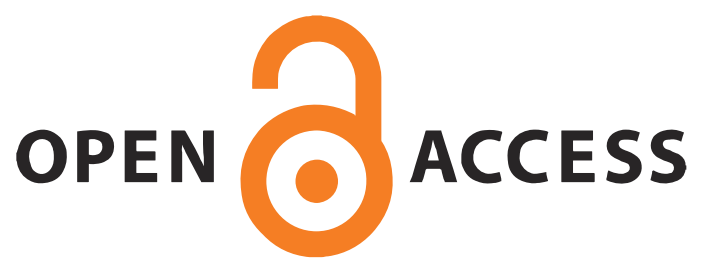




\title{
Theft under Stalin: A Property Rights Analysis
}

\begin{abstract}
Recent work on dictatorship has focused on how repression is used by dictators to eradicate political opposition. This paper examines evidence from one of the most important dictatorships of the twentieth century to suggest that this may tell only half the story. As Stalin's dictatorship progressed, repression was increasingly administered neither by the secret police nor the military_-as in most dictatorships_-but through the ordinary courts. The paper proposes an explanation, one broadly consistent with Mancur Olson's hypothesis that Stalin was a 'proprietary dictator', an autocrat with a long time horizon who made major investments in public goods. Stalin's new form of property—'socialist property'—was one such public good. To legitimize the new form of ownership Stalin ruled that it should be enforced through the ordinary justice system, albeit initially with high levels of repression. The paper also makes two further contributions. It shows, first, how Stalin's theft campaigns are a striking historical example of what happens when an unpopular law clashes with social norms, and of how it might backfire. Secondly, it demonstrates how, as property rights theorists would predict, the main objects of theft legislation are generic or homogeneous goods with few property attributes.
\end{abstract}




\section{Paper}

Recent work on the political economy of dictatorship has focused on how repression is used by dictators to eradicate political opposition. ${ }^{1}$ This paper examines evidence from one of the most important dictatorships of the twentieth century to suggest that this may tell only half the story. In the latter stages of Stalin's rule the system of repression was focused overwhelmingly on ordinary, non-political crime. Towering over all other categories of ordinary crime was theft, the subject of two landmark decrees of 1932 and 1947 which transformed the coercive practices of the Soviet state. By the time of Stalin's death theft accounted for half the population of the Gulag labour camps. Apart from its severity, the most striking feature of Stalinist legislation on theft was the distinction between two categories, "theft of socialist property" and "theft of personal property." The bold distinction in Soviet law between these two categories of property was historically unprecedented and raises a wider question. Why was Stalin's regime so set on this cleavage, making it a centrepiece of the whole system of state-led repression?

The answer, I suggest, lies in property rights. Property rights refer to a set of social rules which determine the uses to which an individual may put a resource. In the Soviet Union, where productive property was in the hands of the state, most property rights were poorly defined. As Harold Berman once noted: "To say that there is state ownership tells us little. For what the state owns no one owns: where the state owns, the question is: who uses, who possesses, who disposes?"2 As with much else, the Soviet dictatorship found a radical solution to this problem. Key property rights were vested in the dictator and enforced by high levels of repression. However this was repression with a difference. Rather than operating through extra-judicial channels, it was administered by the institutions of ordinary justice. The dictator's logic was simple: just as the legal order had entrenched private property in

\footnotetext{
${ }^{1}$ Wintrobe, Political Economy; Gershenson and Grossman, 'Cooption'; Gregory, Terror; Gregory et al., "Rational”; Harrison, "Dictator"; Harrison, "Soviet Union."

${ }^{2}$ Berman, "Soviet Property," 325
} 
Britain during industrialization, so too would the workings of Soviet justice ennoble "socialist property" as a system of property rights for the new socialist state.

The campaigns against theft of socialist property ${ }^{3}$ lend weight to Mancur Olson's argument that Stalin's was a proprietary dictatorship, a position that is closely examined in the paper. The theft campaigns are also interesting, however, for two other reasons. First, they throw new light on the property rights approach and, in particular, on the economic analysis of property rights. ${ }^{4}$ One insight of this approach is that seemingly simple assets may have a number of attributes, but that measuring and policing all may be too costly relative to their value, so that some are surrendered to the public domain or captured by other agents. Grasping the changing costs of delineating and enforcing such rights may be key to understanding certain forms of institutional change. This approach has been adapted to account for the survival of petrol stations, the decline of slavery in the United States, and the criminalization of theft. ${ }^{5}$ The article suggests that it can be applied with profit to the Soviet case, leading to certain predictions, which are examined in greater detail. Secondly, Stalin's theft campaigns provide an unusually clear-cut example of what happens when an unpopular law clashes with social norms. It illustrates how and why such a law might backfire if the agents charged with enforcing it do not share its underlying values. ${ }^{6}$

The paper begins with a literature review. Apart from surveying Olson's work and recent contributions in the property rights tradition, it will assess the literature on repression under dictatorship, and supply a definition and metric of repression. The paper then examines evidence from the Soviet case. In the second section it assesses Stalin's early efforts in the 1930s to establish a high-repression property rights system for socialism. The dictator's

\footnotetext{
${ }^{3}$ Although initially applied rather loosely_and, often, interchangeably with "public property" — by the mid1930s the term "socialist property" had come to denote two specific forms of property: state property, which included the inputs and assets of state enterprises and institutions, and public property, which embraced cooperative property and collective farm property.

${ }^{4}$ Signal contributions include Barzel, Economic; Libecap, Contracting; and Umbeck, "Might."

${ }^{5}$ Barzel, Economic, 21-30, 108-113; Allen and Barzel, "Evolution."

${ }^{6}$ For a recent discussion, see Acemoglu and Jackson, "Social Norms."
} 
attempt to expand and generalize this system after the war is the subject of the third section of the paper. The paper concludes by looking at how and why Stalin's high-repression property system failed and assesses the implications of the evidence for broader understandings of property rights.

I

Stalin's theft campaigns allow us to assess Mancur Olson's notion of a proprietary dictatorship from a new perspective. Olson posited that in order to leave a population with sufficient incentive to generate regular income that he could tax, the rational dictator would stop short of pure "predation" and provide his people with public goods. The extent and form of these public goods would vary with the "encompassing interest" of the dictator in the society, the share of the increase in national income that went to the dictator. In the case of the Soviet Union, Stalin had an unusually large "encompassing interest" and this allowed him to direct the bulk of any growth in social output to meeting his own preferences. With such an exceptionally encompassing interest in the output of his domain "Stalin was, in effect, the owner of the Soviet Union."

For Olson dictators vary with their time horizons. "Many autocrats," he writes, "have had short time horizons: the examples of confiscations, repudiated loans, debased coinages, and inflated currencies perpetrated by monarchs and dictators over the course of history are almost beyond counting." "At the limit, when an autocrat has no reason to consider the future output of the society at all, his incentives are those of a roving bandit and that is what he becomes. ${ }^{, 8}$ For Olson Stalin lay at the other end of the spectrum, an autocrat with an unusually long time horizon.

\footnotetext{
7 Olson, "Hidden Path," 57; and Olson, "Dictatorship," 568-571

${ }^{8}$ Olson, "Dictatorship," 571.
} 
Time horizons are, however, difficult to assess. Neither of the approaches offered by Olson—of tracing a dynasty or calculating the "elapsed duration" of the dictator- have much traction in Stalin's case. Olson's focus on years of expected rule begs the question of why Stalin invested in ever longer-term policies as he neared his own death. ${ }^{9}$ Recent research on the Soviet case has inferred Stalin's time horizons from evidence in the Soviet economy. Gregory and Harrison, for example, depict a leader "obsessed with accumulation" and the allocation of long-term investment, the returns for which would only be realized long after the dictator died. ${ }^{10}$ Another angle on Stalin's time horizon is afforded by looking at his investment in public goods. The theft campaigns were at the heart of Stalin's endorsement of two forms of public good, the administration of justice, and a specific form of public good, a new form of property rights. ${ }^{11}$ Assessing these campaigns allows us to examine Olson's argument from a new perspective and with new evidence.

Despite some mutual scepticism, Olson and some proponents of property rights analysis have much in common. ${ }^{12}$ Property rights theorists distinguish three types of property right: the right of control (i.e. user rights), the right of alienation (i.e. the right to transfer ownership rights), and the right of residual claimancy (i.e. the right to earn and to dispose of residual income from an asset). ${ }^{13}$ To the extent that it posits a direct connection between the individual effort of an owner and the variability of output of her domain, the third of these categories, that of residual claimancy is, writ large, virtually identical to Olson's notion of "encompassing interest" and, indeed, some property rights theorists have extrapolated the

\footnotetext{
${ }^{9}$ Olson, "Dictatorship," 570-71; Clague et al. "Property," 546-49; Olson, Power, 113.

${ }^{10}$ Gregory and Harrison, "Allocation," 530-31.

${ }^{11}$ Along with the administration of justice and defense, the enforcement of property rights is widely recognized as a classic public good, which the state has a comparative advantage in securing. Levi, Rule, 202; North and Thomas, Rise, 7, 94; North, Structure, 17-18, 24; Olson, "Dictatorship," 572; Clague et al., "Property," 245.

${ }^{12}$ For mutual critiques, see Olson, "Dictatorship," 568; and Barzel, Theory, 8

${ }^{13}$ See, for example, Furubotn and Pejovich, "Property Rights," 1140; Kornai, Socialist System, 64-66; Barzel, Economic, 114; Anderson and McChesney, "Introduction," 1.
} 
notion of residual claimancy so that it is used in much the same way. ${ }^{14}$ In fact, Olson's notion of proprietary dictatorship and property rights analysis have other traits in common. Property rights theorists argue that, all else constant, the more clearly property rights are defined, the stronger are the incentives to perform and the better are the prospects for economic growth. One reason, some propose, why command economies were unable to sustain long-term economic growth was that property rights in these systems were fuzzy and ill-defined. However, if this was the case, how are we to account for the high rates of growth in 1930s and 1940s? One answer, shared by Olson and some property rights theorists, is that for a brief period the Soviet Union did have an owner with property rights, and that owner was Stalin. ${ }^{15}$

Property rights theories have other applications which are relevant to our topic. Theft is of interest to property rights analysis as it illustrates vividly how rights are rarely, even in private property rights systems, fully delineated, and how the changing costs of delineation may lead to institutional change. ${ }^{16}$ One example concerns the ending of slavery in the United States. As the population of legally free blacks in the American South grew, and as the distinction between a free person and a slave became harder to establish, the cumulative costs of "theft" (i.e. in the form of escapes) mounted and the net gains from the institution of slavery declined. ${ }^{17}$ Another application is to the criminalization of property offenses in eighteenth century Britain. One factor behind this transformation was the standardization of commodities, which lowered the cost of measuring attributes and, thereby, of contractual exchange. But standardization came at a price. For the more uniform and indistinguishable industrial inputs and outputs became, the easier was it for thieves to transact anonymously

\footnotetext{
${ }^{14}$ See Barzel, Theory, 259-260, 262. On the merging of residual claimancy and ownership in the notion that the residual claimant is the bearer of the variability of her actions, see Alchian and Demsetz, "Production," 783, 794; and Barzel, Economic Analysis, 3-4, 78-79.

15 Riker and Weimer, "Economic," 100; and Poznansky, "Perspective," 79. For an extension of this argument to other property rights regimes, see Acemoglu, "Oligarchic," 1-2, 4-5, 37-38.

${ }^{16}$ Barzel, Economic, 3, 90, 142.

${ }^{17}$ Barzel, Economic, 108-113. A similar approach can be extended to the progressive blurring of penal and free labour in the Gulag labour camps. See Gorlizki and Khlevniuk, Cold Peace, 128-130; and Gregory and Harrison, “Allocation," 738.
} 
without risk of exposure. While consolidating gains from anonymous exchange, standardization facilitated all manner of property offenses. The state responded by hardening its position and treating "wrongful takings" as "thefts."18 One inference from this argument, that strong pressures for introducing theft legislation will come with standardized or generic goods which have relatively few attributes, is examined below.

The paper is also intended as a contribution to the growing literature on repression under dictatorship. Most scholars agree that repression is a key variable that allows us to distinguish between types of dictatorship and to account for how dictatorships evolve over time. ${ }^{19}$ Definitions of repression vary however. One widely held view is that it entails the state's application of physical sanctions against its own population in order to deter perceived threats to a regime. ${ }^{20}$ According to this view, repression is invariably directed at the political opposition. However such a focus leaves out the use of force to promote other goals that may be regarded as priorities by the regime, goals that may have nothing to do with political opposition as such. This may be particularly relevant to dictators, such as Stalin, whose hold on power was relatively secure and who had a longer time horizon. Such rulers could apply the disproportionate use of force, involving major violations of citizens' rights, in order to achieve key regime goals. I will suggest that Stalin's commitment to a new form of property_-"socialist property"—was one such goal.

Those who equate repression with neutralizing political opposition tend to assume that the main institutions of repression are either the military or the security police. Dictators who face violent, organized, and country-wide opposition often have no choice but to rely on

\footnotetext{
${ }^{18}$ Allen and Barzel, "Evolution," 541, 543, 548-50, 558-60; Fletcher, "Metamorphosis," 472, 486, 504-7; Hall, "Theft," 5 .

${ }^{19}$ See for example, Wintrobe, Political Economy, 337.

20 See for example, Davenport, "Political," 2; Davenport, "Tyrannical," 487; Earl, "Political Repression," 262-

3; Goldstein, "Political Repression," xxvii; Acemoglu and Robinson, Economic, 29; and Wintrobe, Political

Economy, 33-34.
} 
the military to quash threats to their regime. In most other cases, however, dictators will prefer the security police for their repression, for fear that over-dependence on the larger and usually more autonomous armed forces may expose the dictator to challenges and possibly even to the threat of a coup. ${ }^{21}$ Scholars tend to assume that it was this latter scenario that prevailed under Stalin. ${ }^{22}$ Fixing on the Great Terror of the late 1930s, Paul Gregory and Mark Harrison, for example, focus almost entirely on the work of the security police in prosecuting individuals through non-judicial tribunals. ${ }^{23}$ By contrast, I suggest that, as Stalin's dictatorship wore on, the main institutional channel of repression was neither the military nor the secret police but the ordinary criminal justice system.

For Gregory and Harrison the fixation with political repression is self-evident and uncontroversial. The logic is simple: "When the dictator needed a mass campaign against his most dangerous enemies, he turned to extrajudicial tribunals. When he wished to move against less dangerous, but possibly more numerous enemies (such as thieves or slackers), he relied on the regular justice system." 24 There are difficulties, however, with this interpretation. First, the dictator regarded thieves of socialist property as among the most dangerous enemies of the Soviet state. As one recent historian observes, for Stalin "socialist property theft... was to be treated as seriously as any form of counterrevolutionary activity." 25 Secondly, the post-war period was also marked by extreme levels of repression. As is apparent from figure 1, in the late 1940s the overall volume of theft convictions, which from 1947 carried extraordinarily harsh punishments, was roughly of the same order as the number of convictions in extra-judicial tribunals a decade earlier. In focusing so heavily on

\footnotetext{
${ }^{21}$ Svolik, Politics, 125, 127; Harrison, "Dictator," 11

${ }^{22}$ For a recent selection, see Harris, Anatomy.

${ }^{23}$ Gregory, Terror, 296; and Harrison, "Dictator," 21.

${ }^{24}$ Gregory, Terror, 22

${ }^{25}$ Shearer, Policing, 21.
} 
1930s Gregory and Harrison lose sight of why and how repression continued at such a high level after the war.

[Figure 1 about here]

I suggest that Gregory and Harrison take too narrow a view of repression. On any reasonable interpretation, death by shooting or exceedingly long terms in remote camps with the associated exposure to disease, malnutrition, and violence for the theft of minute amounts of grain, cloth, or industrial commodities, amounts to a form of repression. Indeed killing, incarceration and hard labour all fall under the category of "personal integrity violations" which, following the work of Poe and Tate, are widely viewed as "the most dramatic form of repression" that exists. ${ }^{26}$ The fact these cases were prosecuted not by the political police or through extra-judicial tribunals does not mean that they did not amount to repression, but that this repression assumed a particular form. That this repression was processed through the ordinary justice system is something that requires explanation and this, I suggest, is to do with the fact it was expected to enforce and, eventually, to legitimize, a particular form of ownership.

Widening our definition of repression to embrace the application of extreme coercion for the commission of non-political offenses has the advantage of opening up new metrics. Data on punishments for ordinary crimes are more reliable than statistics on political offenses. However, such data present problems of their own. Figures on theft convictions are normally the result of two sets of factors: on the one hand the frequency with which people actually stole or appropriated goods, which may have been prompted by a variety of factors such as food shortages, price rises, or the breakdown in social bonds; and, on the other, the

\footnotetext{
${ }^{26}$ See Poe and Tate, "Repression," 853-4; and also Davenport, "Tyrannical," 487; and Escribà-Folch, "Repression," 544.
} 
policy preferences and administrative capacity of the state. ${ }^{27}$ Disentangling the two is not always easy. To deal with this issue, I look at two dimensions. First, I trace the changing volume of convictions over time. Although surges in convictions often had autonomous causes - most notably famine - recent research on the Soviet case suggests that they were also affected by sudden changes in regime policy. ${ }^{28}$ By contrast, the second metric - the punishment regime-was set by the dictator. ${ }^{29}$ This second dimension affords a particular insight into the tradeoffs the dictator was willing to make in order to entrench his new form of property.

Assessment of Stalin's theft campaigns also has a bearing on a third line of research. Historians of the Soviet justice system have long noted that Stalin extended the scope of criminal justice beyond its normal functions and, in so doing, inadvertently underlined the limits of the criminal sanction as a means of social control. The nearer the criminal law approached "naked repression," the greater was the possibility that specific laws "would not be accepted by their enforcers." ${ }^{30}$ Recent game-theoretic models of the interplay between social norms and law enforcement have pointed to a more general finding: to the extent that most laws cannot rely on public enforcement alone but depend on cooperation and reporting by private citizens, any law which runs directly counter to social norms may backfire, as at first some private citizens, and then others, swayed by the formers' example, refuse to enforce it. ${ }^{31}$ In the last part of the paper we look at what happens when a very unpopular law imposed by a dictator runs into conflict with social norms, and assess the impact of this on enforcement of the law by both private and public agents.

\footnotetext{
${ }^{27}$ These factors are sometimes labelled "appropriation" and "control." See Hay, "War," 120.

${ }^{28}$ Hachten, "Property," 305-6, 400, 404.

${ }^{29}$ On this, see Gorlizki, "Rules," 1252-54, 1262

${ }^{30}$ Solomon, Soviet Criminal Justice, 4, 450-2, 463 (quotation at 463). Solomon draws on the seminal work of Herbert Packer, Limits.

${ }^{31}$ Acemoglu and Jackson, "Social Norms," 2-4, 15, 27-28.
} 
Olson wrote of two types of dictator, the predatory "roving bandit" who robbed and confiscated assets with no eye to the future, and the proprietary dictator, who invested in public goods and set exploitation at high but sustainable levels which yielded better returns in the long-term. In the early 1930s the Soviet regime was caught in a titanic struggle with the peasantry over Stalin's goal of extracting a surplus from the countryside. The war with the peasantry was waged on various fronts, but these tended to veer in two directions. One, the policies of Olson's "roving bandit," was encapsulated by Stalin's policy of "liquidating the kulaks as a class." Those peasants deemed "counter-revolutionary" were tried in fast-track extra-judicial tribunals and either executed or despatched to concentration camps, while those branded as "kulak activists" were dispossessed and, along with their entire families, deported to remote wastelands where they were expected to fend for themselves. ${ }^{32}$ By contrast the best and, as it would turn out, the most enduring manifestation of proprietary dictatorship, was the law of 7 August 1932 on theft of socialist property.

The August Law was prompted by the Stalinist regime's drive for grain. Grain was required by the state to feed the growing cities, to sustain non-grain producing areas, and for exports to obtain foreign currency for much-needed machinery. With over $80 \%$ of all sown land sown to grain, it was the quintessential public asset, a "strategic raw material indispensable to the process of running the state." ${ }^{33}$ From the standpoint of the peasant, grain served not only as the chief form of subsistence, but as a means of production (as seed), a raw material for livestock (as forage), and as an exchange good for acquiring industrial commodities. In the ensuing clash between peasant and state it was the latter, famously, that prevailed. When some peasants responded with pitiable acts of hiding, diverting and

\footnotetext{
${ }^{32}$ For excellent summaries, see Khlevniuk, Gulag, 10-12, 16-17; and Lynn Viola, Unkown, 22-24

${ }^{33}$ See Moshe Lewin's classic essay, “Taking Grain,” 142, 147, 169.
} 
siphoning grain in order to save themselves and their families from starvation, Stalin reacted with a law on "theft."

Under the 1932 Law, thefts of "public property" warranted sentences of death by shooting, or, in mitigating circumstances, custodial terms of ten years. ${ }^{34}$ According to Peter H. Solomon, the law "produced a surge of long terms of imprisonment unprecedented in Soviet or, for that matter, Russian, history," and was largely responsible for more than doubling the average custodial term in the USSR by $1934 .{ }^{35}$ Figures from the Russian supreme court showed that in the first eleven months of its operation160,955 people in the Russian Federation (i.e. one, albeit the largest, of the USSR's Union Republics) were sentenced to death or to ten-year terms. ${ }^{36}$ Many of those convicted were peasants, often in the throes of hunger or starvation, given draconian punishments for "offenses" that might include the withholding of negligible quantities of grain to feed their children or non-fulfilment of the sowing plan. ${ }^{37}$ While these cases could, in principle, have been handled by the same extrajudicial tribunals or impromptu farm assemblies that had dispatched the "kulaks" (i.e. the policies of the "roving bandit"), they were not. Why? I suggest two reasons. The first was rooted in the idea that the ordinary justice system might nurture new socialist norms, norms that would in time enforce a new type of property right. The second was grounded in the property attributes of grain, the fundamental resource over which the war between the state and the peasant was fought.

To grasp the first reason we need to go back to the ideological origins of the Soviet state. Karl Marx is sometimes credited as the first modern theorist of property rights, and

\footnotetext{
34 "Public property" appears here in quotation marks as for a period in 1932 it was used interchangeably with the new term "socialist property" but, as we shall see, from mid-1930s the meanings of the two terms would diverge.

${ }^{35}$ Solomon, Soviet Criminal Justice, 119, 222-23.

${ }^{36}$ Figures compiled from Vert and Mironenko, Massovye, 135-36, 138.

${ }^{37}$ For examples, see Vert and Mironenko, Massovye, 140-41
} 
with good reason. ${ }^{38}$ According to Marx, the political power of the bourgeoisie rested in their "property rights" over the means of production. Any direct attack on the institution of bourgeois property was pointless, for not only was it protected in law but this law was "firmly established in the minds of the public as the only one possible in a progressive, free society." ${ }^{39}$ How had this come about? For Marx the place to look was eighteenth century England, a key testing ground in the crystallization of modern understandings of private property. Criminal laws on theft had played a key part in this process: nearly all of the 150 new capital crimes in this period, and approximately three-quarters of all executions, were directed at property offenses. At the same time this violence was crucially tempered, in the words of one neo-Marxist historian, by the "peculiar genius" of the law, whose qualities of majesty, justice and mercy, and whose grand and theatrical settings were mobilized to "deify" property and to "declare [its] sacredness... in terms hitherto reserved for human life."

It was this thread that Stalin picked up. For a new socialist society to form, not only would the institution of private property in the means of production-bourgeois propertyneed to be destroyed, but it would need to be replaced by a new form of property, socialist property. Just as capitalism had declared bourgeois property to be "holy", so too should the Soviet state use all the instruments at its disposal to ensure that socialist property be regarded as "holy and inviolable." ${ }^{41}$

The 1932 Law framed and made real the idea of "socialist property," a concept that was entirely new to the decree. As one Stalin-era treatise would later reflect, "the Law of 7 August for the first time in history defined socialist property as the holy and inviolable

\footnotetext{
${ }^{38}$ E.g. Eggertsson, Economic, 33-34 fn.1; and Anderson and McChesney, "Introduction," 13.

${ }^{39}$ Hazard, "Soviet,' 467

${ }^{40}$ Hay, "Property," 18-9, 48; Hay, "Time," 145.

${ }^{41}$ On the deliberate use of the word "holy" in the August Law that appears to be mindful of the earlier English precedent, see Khlevniuk, Kaganovich, 272
} 
foundation of the Soviet system."42 A number of soon-to-be ideological orthodoxies, authored by Stalin, and which appeared in the August Law for the first time, such as that socialist property constituted the "foundation of the Soviet system," that it was "holy and inviolable," and that "those encroaching on [it] are enemies of the people" made their way (as articles 5 and 131) into the Soviet Constitution of $1936 .^{43}$

The penalties envisaged in the Law were sufficiently severe to elicit the last known example of formal opposition to Stalin at a Politburo meeting. ${ }^{44}$ To the waverers, Stalin countered:

Capitalism would not have destroyed feudalism, nor would it have taken root and consolidated itself had it not been able to assert private property as the foundation of capit[alist] society, had it not made private property holy, had it not punished encroachments on it with the greatest severity, and had it not created its very own state to defend it. So too will socialism not be able to finish off and bury capitalist elements and the individual self-seeking habits which [feed] theft and which undermine the very foundations of our new society if it does not declare public property to be holy and inviolable. $^{45}$

Six months later, in an infamous speech on the progress of the theft campaign, Stalin returned to the theme of "public property" in near-existential terms. "To permit theft and plundering of public property is to aid and abet the disintegration of the whole Soviet

\footnotetext{
${ }^{42}$ Gertsenzon, Istoriia, 388

${ }^{43}$ See Zelenin, "Zakon," 115-16

${ }^{44}$ The objections were raised at a Politburo meeting in Moscow while Stalin was in the south. Although the objection was noted, the relevant names were unfortunately crossed out from the records. See Khlevniuk, Kaganovich, 134, 256

45 Khlevniuk, Kaganovich, 240-41
} 
system.....The main concern of revolutionary legality at present must be the protection of public property and nothing else." ${ }^{, 46}$

Even at the very height of Stalinism the Soviet state had the rudiments of an ordinary system of justice, built around open trials in public courts that heard cases relating to offenses, such as murder and assault, that are criminal everywhere. ${ }^{47}$ Why was the regime so insistent on having theft cases heard in these ordinary courts rather than in the extrajudicial tribunals that had tried the "kulaks"? ${ }^{48}$ We get one clue in a letter finalizing the details of the decree. "I think that in all three points covered by the decree we need to operate on the basis of the law ("the Russian peasant (muzhik) loves legality"), and not simply follow the practices of the [secret police]." ${ }^{49}$ Another hint to Stalin's thinking, and in particular to his perceived need to create new norms around socialist property, can be found in an earlier speech:

What does the arrest of one 'carefree' thief signify? There are hundreds and thousands of them. You cannot get rid of them all with the help of the [secret police]. Another measure, a more important and effective one, is needed. It consists of creating around such petty thieves a climate of moral ostracism and public detestation. It consists of launching a campaign and creating a moral environment...that would make life next-toimpossible for thieves and pilferers of the people's wealth. ${ }^{50}$

To emulate the success of capitalism in creating a new form of property, the first line of defense would have to be the consolidation of a new set of social norms; this was best done "on the basis of legality" in the ordinary courts, rather than in the murky underworld of the secret police's extra-judicial tribunals.

\footnotetext{
${ }^{46}$ Stalin, Works, vol. 13, 214

${ }^{47}$ Berman, Justice, 45; and Solomon, Soviet Criminal Justice, 24, 28.

${ }^{48}$ Although a small fraction of property cases wound up in the extra-judicial tribunals, the Soviet leadership, almost certainly with Stalin's blessing, steered well over four-fifths of such cases to the ordinary courts. Vert and Mironenko, Massovye, 133, 147; Khaustov , Lubianka, 323, 445, 448-50.

${ }^{49}$ Khlevniuk, Kaganovich, 246.

${ }^{50}$ Stalin, Works, vol.8, 143-44
} 
But there was also a second reason why this battle with the peasantry was channelled through the ordinary criminal justice system. This centred on the property attributes of grain, the principal object of the August Law. ${ }^{51}$ Property rights theorists tend to distinguish complex or idiosyncratic assets (such as artisan goods or heirlooms) which may have a large number of attributes, from standardized, generic or homogeneous ones, which have relatively few. ${ }^{52}$ All other things being equal, it is the latter standardized assets that are particularly susceptible to wrongful taking, as they can more easily be sold on without risk of exposure. A wellknown historical example will illustrate the point. ${ }^{53}$ In the course of industrialization in eighteenth century England, previously complex artisan goods were standardized in order to lower the transaction costs of exchange. However, this development also made these goods easier to take illicitly and to sell on without fear that they would be traced. This was one of a number of reasons for the sharp rise in property offenses in this period. The state responded by transferring responsibility for the investigation and prosecution of such cases from private individuals to its own agents who enjoyed scale economies in apprehending offenders and in retrieving lost goods. In this way, property offenses that had previously been treated as civil wrongs or breaches of trust were fully criminalized and treated as "thefts." legislation was the easy part: as one historian notes, "specific, limited property interests," already well-positioned in parliament, were able to get the "Lords and Commons to enact [theft laws] for the mere asking." 55

\footnotetext{
${ }^{51}$ Although grain was not explicitly mentioned in the August decree, the main substantive follow-up resolutions of 23 August and 27 September 1932 focused exclusively on grain. Surveys in late 1932 and early 1933 found that approximately two-thirds of theft cases related to grain or flour. See Vert and Mironenko, Massovye repressii, 130, $134,140$.

${ }^{52}$ See for example Allen and Barzel, "Evolution," 541, 543-44; Barzel, Theory, 163, 167, 169-170.

${ }^{53}$ Although this draws on the English example, the same argument applies to the emergence of the crime of "theft" in other Western European systems. For an excellent discussion of the "topology of theft" in England, France, Germany and Russia, see Fletcher, Rethinking, chap. 1

${ }^{54}$ Allen and Barzel, "Evolution," 543-550. Prior to the Industrial Revolution an individual violating the property rights of another had normally faced private arrest and prosecution and, if found guilty, had been liable to civil damages. Ibid., 547.

${ }^{55}$ Hay, "Property," 20.
} 
By contrast with the products of manufacture, grain, was by nature a homogeneous good. Moreover, it was easily movable and divisible, making illicit appropriation and concealment extremely hard to detect. ${ }^{56}$ As competition for grain increased in the early 1930s, Stalin responded by vesting authority for tracing and retrieving this uniform and easily movable good in the institutions of the ordinary justice system who were deemed better able than the security police to recover lost goods without damage to production. Stalin's job in passing legislation was made all the easier by the fact that he was, by this stage, a dictator: the "owner" of the grain was able to push through a law on the protection of his own property at little cost.

Accounts of the Soviet countryside in summer 1932 abound with stories of how hard it was to track the illicit appropriation and concealment of grain. Peasants employed in mowing, stacking and threshing grain discretely poured small amounts into specially enlarged pockets sown into their clothes while so-called "barbers" (parikmakhery) roamed farm fields in the dead of night and cut off ears of wheat with scissors, sickles and scythes. The grain could then be siphoned off into special pits (iamy) and "black holes" (chernye ambary) dug into the ground. ${ }^{57}$ The Stalinist state responded to this predicament by designating virtually any private possession of grain as a form of "theft." Almost a year into the August Law, a progress report from Andrei Vyshinsky, Deputy Procurator of the USSR, listed some of the "most common methods of theft of grain," including the under-reporting of threshed grain, the over-reporting of spoiled grain, and the mis-weighing of incoming stock at grain collection points. "The protection of grain from theft," ran a parallel order, "needs to be secured at every stage of the production process, right from the harvesting and the threshing

\footnotetext{
${ }^{56}$ Note that the distinction between "movables," which could be stolen, and "immovables," which could not, was absolutely central to early English law on theft. Fletcher, Rethinking, 5; Hall, Theft, 38-41, 45-46, 60-61. ${ }^{57}$ Kondrashin, Golod, 135-37.
} 
of the grain to its transport and reception." ${ }^{\text {58 }}$ At the height of the campaign the state went further by treating any loss, or even prospective loss, of grain as a form of "theft." Thus the practice of redistributing grain to starving peasants as "advance payments" before the commencement of state procurements was vilified by the central administration in Moscow as "pillage of national property." 59 Equally, efforts by some local leaders to press for lower procurement quotas were dismissed by Stalin's secretariat as "theft of public grain.,"60

Implementation of the Law did not go according to plan. One difficulty was that, at the height of the campaign, as justice officials came under pressures from local politicians, ordinary trial hearings often descended into summary procedures which were not far removed from the extraordinary tribunals of the security police. Investigations, usually carried out at great speed, failed to establish the facts of a case, the gravity of the crime, the background of the defendant, or even whether other participants had been involved. Trial hearings, themselves rushed, were often presided over by unqualified officials recruited on the spot. The campaign was marked by vigilantism, the arbitrary seizure of peasant property and mass arrests. As the central government would itself come to admit in May 1933, in going into overdrive the theft campaign in the countryside had begun to erode the authority of the state. ${ }^{61}$ Following a spike in the early months of 1933 application of the Law began to fall back sharply.

By the time of the 1936 Constitution, a campaign for the "stability of laws" was launched which saw a major investment of funds, personnel and training in the institutions of Soviet justice. ${ }^{62}$ At around this time civil law regained some of its former prestige and was mobilized to settle certain questions of ownership, while a variety of concessions were made to personal and

\footnotetext{
${ }^{58}$ Vert and Mironenko, Massovye, 132; Khaustov, Lubianka, 445

${ }^{59}$ Lewin "Taking Grain," 154

${ }^{60}$ Kondrashin, Golod, 136-37.

${ }^{61}$ Solomon, Soviet Criminal Justice, 119-121,125; Khlevniuk, Khoziain, 243.

${ }^{62}$ Huskey, "Vyshinskii"; Solomon, Soviet Criminal Justice, chap. five.
} 
other forms of "non-state" (i.e. collective farm and cooperative) ownership. ${ }^{63}$ However, although the August Law had largely fallen into disuse it had left an important legacy. It had introduced socialist property as a distinct entity in Soviet criminal law; it had allowed the possibility that high levels of repression could be used to protect it; and it had elevated its defense into one of the cardinal missions of the whole Soviet legal order. Further, the decree sealed a historically novel distinction between the stealing of public property and the theft of property of individual citizens. ${ }^{64}$ In keeping with Olson's notion of a proprietary dictator, Stalin had created an institution for the long haul. For while socialist property was initially to be supported by high levels of repression, in the longer term it was to be self-sustaining and supported by its own social norms. The theft law, as the Politburo member, Lazar Kaganovich, was quoted as saying, "is a great law (velikii zakon). Such laws live for decades, even centuries." "Its form may change," commented one official in 1936, "but its principles will last.",65

III

In June 1947 Stalin launched a pair of decrees on theft which would alter the landscape of repression for the duration of his dictatorship. The decrees were not merely the ill-thought and despotic actions of a wilful dictator bent on controlling his citizens through force. They were a particular response to growing problems he faced in managing and controlling state resources. As in 1930s, the dictator used the theft decrees as a high-repression instrument for defining "socialist property" and for making it recognizable to Soviet citizens. But whereas in early 1930s the main prompt for the August decree had been grain, a naturally generic good of great strategic value, by 1940s, with the expansion of the centrally managed economy, it was joined by low-attribute inputs and outputs of the industrial process which were also vulnerable to theft. In a parallel to the appropriation

\footnotetext{
${ }^{63}$ Hazard, "Soviet," 474-75, 479-8; Berman, "Soviet Property," 325.

${ }^{64}$ On the novelty of this distinction in Russian law, see Berman, Soviet Criminal Law, 36, 137; and Sergeeva, Ugolovno-pravovaia, 10-11. The bold distinction in Soviet law was also unprecedented in comparative terms. Probably the nearest thing is the inferred but never explicitly stated contrast in Chinese Law. On this see Jones, "Theft," 508-9.

${ }^{65}$ Zelenin, "Zakon," 117; Golunskii, "Proekt," 48.
} 
of standardized inputs such as coal, iron and cloth at the workplace in industrializing England in the eighteenth century, the rise of standardized goods in Soviet factories played its part in triggering a new round of legislation. ${ }^{66}$

After the war, as in 1932, the main catalyst for the hardening of the regime's policy on theft was the worsening grain situation. The most important factor behind the new "struggle with theft" - as in 1932 — was a major famine which exacerbated competition for grain. A second factor, however, was that grain, as a generic and easily divisible good, exposed major failures in the state's accounting and inspection mechanism. A high-level report in mid-1946 lamented that proper inventories of grain stocks were not taken, that auditing commissions did not operate as required, and that grain was sometimes simply distributed in exchange for "fictitious receipts." ${ }^{67}$ By midDecember 1946, with a bare $77 \%$ of the procurement plan for grain fulfilled, guards, drivers, railway workers, heads of collective farms and peasants were being charged with "mass thefts." 68

However, unlike the early 1930s "theft of socialist property" was no longer confined to one sector of the economy or to one segment of the population. Figure 2 shows how, even before the war there was a growth in the proportion of theft cases in the towns and cities. ${ }^{69}$ It also shows a substantial rise in the proportion of thefts committed by workers. One factor appears to have been the burgeoning thefts of ration cards and coupons - a classic generic good-with the onset of the war. However, there was also a major rise in on-the-job thefts of raw materials and basic tools used in the making of consumer goods, which had become extremely scarce with the conversion of industry to military ends. ${ }^{70}$ In the immediate aftermath of the war a major hike in the price of factory-made consumer items sparked off an epidemic of "gleaning" (taking generic scrap material

\footnotetext{
${ }^{66}$ On the English case, see Allen and Barzel, "Evolution," 548-9, 555-56, 561-62

${ }^{67}$ Vert and Mironenko, Massovye, 559

${ }^{68}$ Vert, Terror, 368-70.

${ }^{69}$ The reasons for this are not entirely clear. One factor may have been the formation of a new department for combating theft of state property (OBKhSS) in March 1937, whose offices were mainly in the towns. On this, see Heinzen, "Informers," 801-2.

70 Hessler, Social History, 268
} 
from production) in factories. ${ }^{71}$ In Ivanovo oblast in the second half of 1946, 9,600 workers were arrested for the "theft of cloth and thread at enterprises." In some regions the number of those caught red-handed was so high (for example, $40 \%$ of those employed at the Tashkent Textile Combine), that factory directors simply refused to press charges. ${ }^{72}$ Figure 3 shows that the war saw the greatest divergence between the two main sets of statistics for theft convictions. Whichever statistics one uses, the volume of theft convictions rises markedly, then falls back slightly at the end of the war, before rising again during the famine-stricken year of 1946.

[Figures 2 and 3 about here]

The dictator's response to these developments was to ramp up repression to previously unimaginable levels. Initially the response was targeted, but by 1947 Stalin decided on a more sweeping approach. ${ }^{73}$ Under the decrees of 4 June, minimum terms for theft of state property were raised from six months to seven years and for theft of personal property from three months to five years, while in the most serious cases the upper limits were raised to 25 years. $^{74}$

The impact of the decrees was dramatic. Average sentences for theft of socialist property were pushed up from 3.2 years to 8.7 years while those for theft of personal property rose from 1.3 to 6.2 years. Remarkably, for the rest of the Stalin period the average sentence for theft of socialist property exceeded that for premeditated murder $(7.3$ years $) .{ }^{75}$ As with the 1932 Law, the June theft decrees transformed the Soviet penal system. In 1947 alone, twenty-seven Gulag camps were opened to accommodate the flow of new inmates. In all, between 1947 and 1952, approximately one and a half

\footnotetext{
${ }^{71}$ On "gleaning" and its connection to theft legislation in eighteenth century England, see Allen and Barzel, "Evolution," 548-9, 555-6, 561-2.

${ }^{72}$ Vert, Terror, 366-67, 374

${ }^{73}$ As the 1946 procurement campaign ran into trouble, 12,500 collective farm chairs and 6,900 functionaries from the rural soviets were arrested. Vert, Terror, 370

${ }^{74}$ There were two decrees. The first, on theft of socialist property formally introduced the distinction between theft of "state property" (articles 1 and 2), with a minimum of seven years, and theft of "kolkhoz, cooperative and other public property" (articles 3 and 4), which had a lower minimum tariff of five years. The second decree was entitled "On safeguarding the personal property of citizens." See "Ob ugolovnoi" and "Ob usilenii."

75 Averages prior to the decrees are calculated from January 1946 to June 1947 and after the decrees from July 1947 to December 1952. GARF f.9492 op.6s d.14 11.30-31; Gorlizki, “Theft," 19, 25
} 
million people were convicted of theft of socialist property and a further 700,000 of theft of personal property, so that by the time of Stalin's death almost a half of the Gulag population were serving terms under the two decrees. ${ }^{76}$ Never falling below a third of all court cases, the 1947 decrees almost singlehandedly reoriented the courts' sentencing policy. Figure 4 shows that although punishments of between six to ten years had not been entirely stable prior to the June decrees, for example tripling between 1940 and 1942, they increased six-fold from 1946 to 1948. Perhaps more strikingly, terms of ten years and over shot up over three hundred times over the same period. As a proportion of all punishments, custodial terms of six years and over climbed from 4-7\% in the early 1940s to approximately $30 \%$ in the years that followed the decrees. ${ }^{77}$

[Figure 4 around here]

Apart from their repressiveness, the decrees were distinguished by their overarching concern with property. Their ideological point of origin was the statement, which first appeared in the 1932 August Law, but which was then enshrined in the 1936 Constitution, that it was not "thieves" as such who were "enemies of the people" but "those who encroach on public (socialist) property." "The preservation of public property," ran an editorial of the journal Sotsialisticheskaia zakonnost', "acquires special significance now, in these postwar conditions, as the Soviet state devotes every kopek, every kilogram of metal and coal, and every litre of fuel, to the most rapid reconstruction and development of our economy.,"78

According to economic analysis of property rights, most assets or resources will have a number of "property attributes." In law the presence of attributes is reflected in a multiplicity of property-related offenses, often involving quite subtle distinctions. The June decrees swept these aside. Deeming any incursion on "socialist property" a form of "theft" they took as their cue not

\footnotetext{
${ }^{76}$ GARF f.9492 6s d.14 1.18; Gorlizki, "Rules," 1260; Vert, Terror, 364

${ }^{77}$ A small fraction of this increase was due to new policies on rape, banditism and murder, whose cases, collectively, were only $3.7 \%$ of the numbers convicted of theft. GARF f.9492 op.6 d.14 11.20, 24, 29-31; Gorlizki, "Rules," 125354; Vert, Terror, 363-64, 374, 427.

78 "Desiat' let," 12; 'Usilit' bor'bu," 1.
} 
the nature of the crime nor the intentions of the offender, but the effects of the act on "socialist property." The decrees collapsed traditional distinctions in Soviet law between open and secret stealing (otkrytoe pokhischenie and krazha), as well as between ordinary stealing and stealing by means of embezzlement (rastrata), swindling (moschennichestvo), extortion (vymogatel'stvo), cheating and mis-selling (obmerivanie and obveshivanie pokupatelei), and various forms of indirect "misappropriation" (prisvoenie), now compressing these offenses into the one all-encompassing category of "theft" (khischenie) ${ }^{79}$ As the legal scholar S.A. Bordonov concluded: "the decree envisages theft (khischenie) committed by any means. This is completely obvious given that, irrespective of how it is committed, khischenie weakens the economic strength of the motherland." 80

When it came to the theft decrees the dictator had little compunction in suddenly scaling up repression. He was also happy to "simplify" the judicial process by introducing strictly binding upper and lower tariffs, eliminating alternatives, and agglomerating a wide array of offenses under the broad canopy of "theft." 81 However, despite their enormous caseload, the campaigns against theft avoided the shortcuts deployed in the sphere of political justice in the late 1930s. Whereas even after the war, most counter-revolutionary cases were heard in extra-judicial settings ${ }^{82}$ the vast majority of socialist theft cases from 1946 until Stalin's death—95.2\%—were heard in open session in the "general jurisdiction courts" (sudy obschei podsudnosti) ${ }^{83}$ The fact that thieves were tried overwhelmingly in general jurisdiction courts was not because they were regarded in some sense as "second-order" criminals—in the late 1940s they were still cast as "enemies of the people"

\footnotetext{
${ }^{79}$ Goliakov, “'Usilenie,” 5; Utevskii and Vyshinskaia, Praktika, 12-13, 20, 31-50, 54-61; Sergeeva, Ugolovno-pravovaia, 12, 25-6.

${ }^{80}$ Bordonov, Narodnyi sud, 9 (italics mine)

${ }^{81}$ On the "exceptional simplicity and clarity" of the theft decrees, see Goliakov, "Protiv," 20, 23; Goliakov,

"Usilenie," 5. On the wide range of offenses that were now treated as "theft" see Sergeeva, Ugolovno-pravovaia, 17; Utevskii and Vyshinskaia, Praktika, 61-63.

${ }^{82}$ Over 88\%, as calculated from GARF f.9492 op.6s d.14 1.8; Artizov, Reabilitatsiia, 73.

83 As calculated from Vert and Mironenko, Massovye, 618; GARF f.9492 op.6s d.14 1.18.
} 
and, in some formulations, as the "enemies of socialism" $" 84$-but because the purpose of the theft campaign, of "defending the economic foundations of socialism," was best achieved in open trials. In its ideology the regime clung to a long-term vision in which the courts would foster new norms around socialist property, norms which would eventually crystallize as property rights.

IV

The establishment of a new form of property, "socialist property" (in effect the property of the dictator), the investment of resources in a public good (the administration of justice), and the marked shift from extraordinary tribunals to ordinary courts all appear to corroborate Olson's notion of Stalin as a proprietary dictator. Olson also postulated that the proprietary dictator with his "encompassing interest" in the output of society would fight off tightly organized coteries which, enjoying "only a miniscule share of any increase or decrease in society's output," pursued narrow, sectional interests, usually to the detriment of growth and social output. ${ }^{85}$ The evidence we have suggests that Stalin went to great lengths to stamp out any form of lobbying, special pleading or collusion at the upper reaches of the system. ${ }^{86}$

However developments over Stalin's last years point to flaws in Olson's model. The cost of enforcing exclusive rights will fall when the public hold norms that coincide with these rights. Further, property rights, even if they are a dictator's, will be more stable if they are enforced by independent society-wide institutions in which the owner plays no part. Stalin's property system had the benefit of neither set of conditions. First, despite its advantages, operating through the ordinary criminal justice system, as opposed to the preferred instrument of the "roving bandit", the extra-judicial tribunals, incurred major transaction costs. The main organization charged with investigating and prosecuting theft cases was the Soviet procuracy. Like other large-scale Soviet civil

\footnotetext{
${ }^{84}$ Eg Gertsenzon, Istoriia, 6-7, 372, 388

${ }^{85}$ Olson, "Hidden Path," 56-58

${ }^{86}$ Gorlizki and Khlevniuk, Cold Peace, 79-89, 108-113, 124-141
} 
organizations of the period, the procuracy issued rules and set bureaucratic standards to maintain the work quality of its officials. Observance of these standards had the effect of inhibiting all-out enforcement of the 1947 decrees. In particular, early implementation of the theft campaign sharply pushed up rates of supplementary investigations, terminations and time-violations, on which the individual procuracy official was assessed. In order to bring these levels down and protect their own careers and reputations, procurators became more selective and discriminating in the cases they brought to court. This was one of a variety of reasons why, from the beginning of 1948, the volume of theft cases prosecuted under the June decrees began to fall. ${ }^{87}$

Secondly, the extremely high levels of repression envisaged by the theft decrees ran counter to public norms. While no surveys of popular opinion were carried out in the late Stalin period, the theft decrees were sufficiently severe to elicit strong reactions, in the forms of tens of thousands of letters, complaints and appeals to Moscow, which were not only noted, but acted on by justice leaders, as the following letter from the procurator general, Grigori Safonov, to the Central Committee Secretary, Andrei Zhdanov, in June 1948 illustrates:

The court must hand down a penalty of no less than seven years' deprivation of freedom for the theft of a pair of galoshes, for the theft of three metres of satin, etc. Sometimes such sentences are totally incomprehensible to citizens, and create the impression that the severity of the penalty does not fit the crime, since penalties for other serious crimes are clearly lower than those for theft. ${ }^{88}$

According to one study, two-fifths of the appeals to the USSR supreme court in 1949 concerned just one law, the June decree on theft of socialist property. ${ }^{89}$ An examination of individual letters gives a flavour of some of the concerns. One group of workers from Sverdlovsk

\footnotetext{
${ }^{87}$ Gorlizki, "Rules," 1255-61

${ }^{88}$ Filtzer, Soviet Workers, 253(italics mine).

${ }^{89}$ Heinzen, Art of the Bribe, chap 8. fn.98, cited with permission.
} 
in December 1949 were aghast that teenagers, many of whom were homeless or on the breadline, were being incarcerated, often for the most trivial of property offenses.

Over half the people rotting in prison are there for petty thefts, getting seven years, for example, for walking off with a couple of kilos of frozen potatoes. Most of these people are youths, and some are our own children..$^{90}$

According to Acemoglu and Jackson, one of the difficulties with laws which run counter to social norms is that they deter private enforcement from ordinary citizens in the form of reporting and "whistle-blowing." 91 This was almost certainly the case with the theft laws. However, the decrees not only offended the values of Soviet citizens, but ran against the personal ethics of the state's own agents. Even before they could come before judges, many thefts were either not reported by militsiia officers or by factory or kolkhoz managers, or the cases were furtively dropped by investigators. Police and procurators were sometimes reluctant to prosecute starving peasants, single mothers, often war widows, struggling to support a family on one salary, while managers and administrators often failed to report much-needed employees and officials who were hard to replace. For their part, judges continued to apply articles that were supposed to have been displaced by the June decrees, and to make use of loopholes in the code that allowed them to soften punishments. ${ }^{92}$ Growing unease with the decrees eventually culminated in a joint letter to Stalin from the heads of the three main justice agencies, the minister of justice, the procurator general, and the chair of the supreme court, in spring 1951. Citing, among others, a stevedore given ten years for appropriating two kilos of wheat and a widow and mother sent to camp for seven years for stealing a kilo of rice, the justice leaders begged the dictator to reintroduce the decree on of 10 August 1940, with its much lighter sentences, for "minor, insignificant thefts.",93

\footnotetext{
${ }^{90}$ Zubkova, Sovetskaia Zhizn', 449; also see 451.

${ }^{91}$ Acemoglu and Jackson, "Social Norms."

${ }^{92}$ Solomon, Soviet Criminal Justice, 430, 435-39

${ }^{93}$ Vert and Mironenko, Massovye, 568-70
} 
So long as Stalin lived all efforts at reform were blocked and the close linkage between his personal dictatorship and the primacy of "socialist property" held firm. By the same token it was testimony to this linkage that with the dictator's death the absolute priority of "socialist property" in Soviet legal thinking quickly unravelled. In May 1956 the party’s leading theoretical journal, Kommunist, launched a blistering attack on the "well-known position that the main concern of revolutionary legality in our time consists in the protection of socialist property and in nothing else" and two months later it condemned the "one-sided interpretation of legality" whereby "everything is reduced to the protection of public property." 94 Actual reform of the 1947 theft laws came even earlier. In May 1954 the USSR Supreme Court reversed a hard-line resolution passed on the eve of Stalin's death, which had given unqualified backing to the June decrees, and by the end of 1955 one senior official reported that "in over a half the cases of theft of state and public property [in 1954 and 1955], the courts are no longer guided by the June decree." ${ }^{95}$ Thereafter, the dismantling of Stalin's property system proceeded apace, culminating in the new Russian criminal code of 1960 which slashed the penalties for ordinary theft of state property, restored traditional Russian distinctions between types of theft, and introduced a range of fine gradations in punishment. $^{96}$

Why did Stalin's property system fall apart so quickly? There appear to be two reasons. First in its pure form the authority to dispose of socialist property had belonged to the dictator, Stalin, whose personal authority transcended the Politburo. With Stalin dead this authority was now transferred to a collective riven by infighting, where rival leaders had no choice but to court special interest groups, each pressing their own narrow goals. ${ }^{97}$ With this the rulers' "encompassing interest" in Soviet society quickly fragmented. Secondly, Stalin's proprietary dictatorship rested on extremely high levels of

\footnotetext{
${ }^{94}$ Rakhunov, "Sovetskoe," 44; "Ukreplenie," 20.

${ }^{95}$ Vert and Mironenko, Massovye, 591, 602

${ }^{96}$ Minimum punishments for theft of state property were reduced from seven years to three months' deprivation of freedom or correctional tasks, while the maximum fell from ten years to three. Berman, Soviet Criminal Law, 55-57.

${ }^{97}$ For a discussion, see Gorlizki and Khlevniuk, Cold Peace, 166
} 
repression, but these clashed with public norms. Earlier we introduced two metrics of repression, the tariff, or severity, of punishment, and the volume of cases. Had Stalin exercised genuine property rights, and had these chimed with the values or norms of the population at large, one might have expected the regime's use of repression to have been kept at a low but steady level. Owing to the notorious harshness of its punishments for property offenses, eighteenth century England is again a useful point of comparison. Although the death penalty was used, there was in England "a remarkably stable average rate of about 100 [executions] per year...throughout the eighteenth century."98 "Too many executions," observes one historian, "might have weakened the law's acceptance and hardened further the hearts of those whom exemplary punishments were designed to reach and control." ${ }^{, 99}$ In fact, although secondary punishments for property offenses, especially transportation to America, grew after 1718, overall indictments for theft do not appear to have exceeded a few thousand a year at any point in the century. ${ }^{100}$ By contrast, Stalin observed no such threshold. In 1947 approximately 400,000 people were sentenced to draconian terms for theft of socialist property. Moreover, from Figure 5 we can observe two trends. First although there was some variance in the total number of convictions for serious crimes (i.e. those requiring preliminary investigation), it kept within a range of $50 \%$ of 1939 levels. However, behind these headline figures there was a major divergence: the huge increase in theft cases stretched the capacity of the state and limited its ability to prosecute crimes against the person, levels for which in normal circumstances are quite stable. With the state already under pressure, the theft campaign took a major toll on the ability of the justice agencies to secure convictions for crimes other than theft. Secondly, as the volume of cases began to trail off, in 1952 it was Stalin's personal intervention that temporarily reversed the trend, leading to a discernible peak on the eve of his

\footnotetext{
${ }^{98}$ Quotation from Hay, "Time," 145. Also see Hay, "Property," 22; Hay, "Crime and Justice," 49, 64-65; Beattie, Crime, 588-9.

99 Beattie, Crime, 587; and see Hay, "Property," 57.

${ }^{100}$ Figures extrapolated from Beattie, Crime, 202-3, 214.
} 
death. ${ }^{101}$ Without a system of self-enforced property rights, Stalin had to work tirelessly to keep his high-repression property system in tact. ${ }^{102}$

Figure 6 shows the volume of theft convictions in a wider historical perspective. Although levels prior to the First World War were also unstable, almost doubling from 1900 to 1913, they only reached a sixth of the levels attained in 1947, and this leaves to one side the fact that theft sentences under the Tsars were only a fraction of those imposed by Stalin.

[Figures 5 and 6 about here]

V

On the face of it the Stalinist dictatorship is not an obvious candidate for property rights analysis. To the extent that they attach to individuals all property rights are by definition "private." For ideological reasons the "socialized" centrally managed economy was reluctant to assign rights to individuals, leaving a system of property rights that was fuzzy and ill-defined. The Stalinist system also involved extremely high levels of repression. The use of violence in the allocation of resources, usually attended by waste and uncertainty, is widely regarded as the very antithesis of a secure and stable system of property rights. So why apply a property rights approach? I have suggested three reasons. First, for roughly twenty years some form of property rights were exercised by an individual: the dictator, Joseph Stalin. This was matched by heavy investment in a new form of property— “socialist property," in effect the dictator's property-whose prominence quickly receded with the dictator's death. Secondly, property rights were embodied in Soviet ideology. Marx had argued that "bourgeois" property rights had laid the ideological foundations for capitalism; Stalin wanted "socialist" property rights to do the same for socialism. Whether Stalin actually believed in what he said is immaterial. The key thing is that in order to win support he

\footnotetext{
${ }^{101}$ Gorlizki, "Theft," 22-23.

${ }^{102}$ I owe this point to Valery Lazarev.
} 
tapped into the ideological discourse. ${ }^{103}$ It was ideology that stretched Stalin's time horizon; without understanding this much of Stalin's behaviour makes little sense. ${ }^{104}$ Thirdly, the economic analysis of property rights offers a useful prediction which is largely borne out by the Soviet case: it is generally homogeneous objects with relatively few attributes, such as grain, or standardized inputs at the workplace, that are the most likely to trigger legislation on theft.

One benefit of this study is that it allows us to extend the tools of property rights analysis to a wider range of property rights systems and, in so doing, to explore the connection between the protection of property and the state's use of repression. ${ }^{105}$ This brings out a major contrast between private and socialist property systems. In private property systems the state has the advantage of being able to rely on the self-interest of owners to protect their own property from theft, for example by putting up fences, installing locks, hiding valuables, hiring guards, or suing for damages. ${ }^{106}$ It was because the Soviet state could not rely on these incentives that it resorted to force; it is this that explains the extremely high levels of repression of the late 1940s, levels which surpassed and eventually eclipsed the use of state violence to deal with political opposition.

Analysis of theft under Stalin also points to drawbacks in certain variants of the property rights approach. One fault with the Olson model is that it pays insufficient attention to the role of institutions. In the theft campaigns the institutions of justice incurred major transaction costs, and without taking these into account it is hard to explain much that is of interest to our story, such as the trajectory of theft cases. A broader flaw with economic analyses of property rights is the

\footnotetext{
${ }^{103}$ In this sense Olson was perhaps more accurate than he himself realized. Olson sensed that Stalin had a long time horizon but he did not know why. Here his dismissal of ideology is misguided. One reason is that not all theories of ideology are cognitive. Some suggest that political actors may gain from established discourses irrespective of whether they believe in them. Olson, Power, 112-13, 130. On non-cognitive theories of Soviet ideology, see Schull, "What is Ideology?"

${ }^{104}$ This is why some general theories of dictatorship get Stalin wrong. A case in point is Roger Myerson who, in developing a model of dictatorship that focuses entirely on the formative stages of a new dictatorship and on short time horizons is forced to concede that Stalin's dictatorship is "an exceptional case that necessarily involves a failure of rational expectations." Myerson, "Credibility," 136. Cast in more general terms, Gandhi also suggests that, all else equal, dictators are particularly prone to favour policies with short time horizons. Gandhi, Political, 112.

${ }^{105}$ Earlier efforts include Umbeck, "Might," 39-41, 51, 57; Haddock, "Force," 169

${ }^{106}$ Barzel, Economic, 117-18, 141-42; Olson, Power, 103-4
} 
underestimation of social norms. ${ }^{107}$ Property rights are "socially recognized rights of action": what this means is that what are owned are not the assets themselves but rights to use them in specific ways. ${ }^{108}$ But in what ways are these "rights"? Economic analysts sometimes distinguish legal rights, which are assigned to a person by the state, from economic rights, which refer to a person's ability to enjoy a piece of property. As an example they cite thieves, who may lack legal rights over the goods they steal, but can still consume the good, exclude others from using it and derive income from it, all of which are economic rights. ${ }^{109}$ But it is not clear what is gained by referring to these capabilities as "rights." ${ }^{110}$ Here we may do well to take a leaf out of an earlier generation of property rights theorists. As Armen Alchian noted in early 1960s, "private property rights are rights not merely because the state formally makes them so but because individuals want such rights to be enforced"; they come about "not merely by laws backed by the police force, but by social acceptance, reciprocity, and voluntary social ostracism for violators of accepted codes of conduct." "111 Evidence from Stalin's campaigns on theft of socialist property suggests that these norms were absent, not only from society at large but from the criminal justice bureaucracies that were supposed to implement them, and it was for this reason that Stalin's high-repression property system collapsed so quickly.

\footnotetext{
${ }^{107}$ This is somewhat ironic as originally this approach was thought to be particularly well suited to the study of customs, norms and values. See, for example, Eggertsson, Economic Behavior, chap 9.

108 Alchian and Demsetz, "Paradigm," 17. For a forceful critique that property rights analyses are not about "property" (i.e. a "right to a thing good against the world") at all, see Merrill and Smith, "What Happened," 358-60, 377-78

${ }^{109}$ Barzel, Economic, 3, 90-91, 141

${ }^{110}$ For an excellent analysis in these terms, see Cole and Grossman, "Meaning," 322, 325, 327

${ }^{111}$ Alchian, "Some Economics," 129-30 (italics mine)
} 


\section{REFERENCES}

Acemoglu, Daron. "Oligarchic Versus Democratic Societies." Journal of the European Economic Association 6, 1 (2008): 1-44

Acemoglu, Daron, and Matthew O. Jackson. "Social Norms and the Enforcement of Laws." NBER Working Paper 20369, August 2014

Acemoglu, Daron, and James A. Robinson. Economic Origins of Dictatorship and Democracy. New York: Cambridge University Press, 2006.

Alchian, Armen A. "Some Economics of Property Rights.” Il Politico 30 no.4 (1965): 816-829, reproduced in Armen A. Alchian, Economic Forces at Work, 127-49. Indianapolis: Liberty Press, 1977.

Alchian, Armen A., and Harold Demsetz. "The Property Rights Paradigm.” Journal of Economic History 33, 1 (1973): 16-27.

"Production, Information Costs and Economic Organization." The American Economic Review, Vol. 62, No. 5 (Dec., 1972): 777-795

Allen, Douglas W., and Yoram Barzel. "The Evolution of Criminal Law and Police during the Premodern Era." Journal of Law, Economics and Organization 27, no. 3 (2011): 540-67

Anderson, Terry L., and Fred S. McChesney, "Introduction: The Economic Approach to Property Rights." In Property Rights: Cooperation, Conflict and Law, edited by Terry L. Anderson and Fred S. McChesney, 1-19. Princeton: Princeton University Press, 2003.

Artizov, A., et al. Reabilitatsiia: Kak eto bylo. Dokumenty Prezidiuma TsK KPSS i drugie materialy. Mart 1953-fevral' 1956. Vol.1. Moscow: MFD, 2000.

Barzel, Yoram. Economic Analysis of Property Rights $2^{\text {nd }}$ ed. New York: Cambridge University Press, 1997.

A Theory of the State: Economic Rights, Legal Rights, and the Scope of the State. Cambridge: Cambridge University Press, 2002.

Beattie, J.M. Crime and the Courts in England 1660-1800. New Jersey: Princeton University Press, 1986.

Berman, Harold J. "Soviet Property in Law and Plan." University of Pennsylvania Law Review 96, no. 3 (1948): 324-53 Justice in Russia. Cambridge, Mass.: Harvard University Press, 1950.

. Soviet Criminal Law and Procedure: The RSFSR Codes. Cambridge, Mass: Harvard University Press, 1966.

Bordonov, S.A. Narodnyi sud na strazhe sotsialisticheskoi sobstvennosti. Moscow: Gosiurizdat, 1954.

Clague, Christopher, Philip Keefer, Stephen Knack, and Mancur Olson. "Property and Contract Rights in Autocracies and Democracies." Journal of Economic Growth, 1 (1996): 243-276

Cole, Daniel H., and Peter Z. Grossman. "The Meaning of Property Rights: Law versus Economics?" Land Economics, 78, 3 (2002): 317-330

Davenport, Christian. "State Repression and the Tyrannical Peace." Journal of Peace Research 44, 4 (2007): 485-504 23

"Desiat' let Stalinskoi Konstitutsii pobedivshego sotsializma." [Editorial] Sotsialisticheskaia zakonnost' no.11-12 (1946): 8-13

Earl, Jennifer. "Political Repression: Iron Fists, Velvet Gloves, and Diffuse Control." Annual Review of Sociology 37 (2011): 261-284

Eggertsson, Thráinn. Economic Behaviour and Institutions. Cambridge: Cambridge University Press, 1990.

Escribà-Folch, Abel. "Repression, Political Threats, and Survival under Autocracy." International Political Science Review, 34, 5 (2013): 543-560

Filtzer, Donald. Soviet Workers and Late Stalinism: Labour and the Restoration of the Stalinist System after World War II. Cambridge: Cambridge University Press, 2002.

Fletcher, George P. “The Metamorphosis of Larceny.” Harvard Law Review, 89, 3 (1976): 469-530 Rethinking Criminal Law. Boston: Little, Brown and Company, 1978. 
Furubotn, Eirik G., and Svetovar Pejovich, "Property Rights and Economic Theory: A Survey of the Literature," Journal of Economic Literature, 10 (1972): 1137-1162.

Gandhi, Jennifer. Political Institutions under Dictatorship. Cambridge: Cambridge University Press, 2008.

GARF (Gosudarsvennyi Arkhiv Rossiiskoi Federatsii) State Archive of the Russian Federation. f.5446 op.86a. Fond of the USSR Council of Ministers, inventory for the Administration of Affairs [upravlenie delami]. Moscow.

. f.9474 op.16c. Fond of the USSR Supreme Court, inventory for the Chief Administrative Office [kantseliaria]. Moscow. . f.9492 op.6. Fond of the USSR Ministry of Justice, inventory for judicial statistics. Moscow.

Gershenson, Dmitriy, and Herschel I. Grossman, "Cooption and Repression in the Soviet Union," Economics and Politics, 13, 1 (2001): 31-47

Gertsenzon, A.A., et al. Istoriia sovetskogo ugolovnogo prava. Moscow: Gosiurizdat, 1948.

Goliakov, I. "Usilenie okhrany gosudarstvennoi, obschestvennoi i lichnoi sobstvennosti." Sotsialisticheskaia zakonnost' no.9 (1947): 4-7.

. "Protiv izvraschenii smyslia ukazov ot 4 iunia 1947 goda." Sotsialisticheskaia zakonnost' no.11 (1947): 20-23.

Golunskii, S. "Proekt Konstitutsii SSSR i zadachi prokuratury." Sotsialisticheskaia zakonnost' no.7 (1936): 48-52.

Gorlizki, Yoram, and Oleg Khlevniuk. Cold Peace: Stalin and the Soviet Ruling Circle, 1945-1953. New York: Oxford University Press, 2004.

Gorlizki, Yoram. "Rules, Incentives and Soviet Campaign Justice after World War II." Europe-Asia Studies 51, 7 (1999): 1245-1265.

Gorlizki, Yoram. "Theft under Stalin: A Property Rights Analysis.” PERSA Working Paper no. 10 (2001). http://warwick.ac.uk/persa (accessed on 10 August 2014)

Gregory, Paul R. Terror by Quota: State Security from Lenin to Stalin (An Archival Study). New Haven: Yale University Press, 2008.

Gregory, Paul R., Philipp J.H. Schröder, and Konstantin Sonin, "Rational Dictators and the Killing of Innocents: Data from Stalin's Archives," Journal of Comparative Economics, 39, 1 (2011): 3442

Gregory, Paul, and Mark Harrison. "Allocation under Dictatorship: Research into Stalin's Archives." Journal of Economic Literature, 43 (2005): 721-761

Hachten, P. Charles. "Property Relations and the Economic Organization of Soviet Russia 19411948." Ph.D. dissertation submitted to the University of Chicago, 2005.

Haddock, David D. "Force, Threat, Negotiation: The Private Enforcement of Rights." In Property Rights: Cooperation, Conflict and Law, edited by Terry L. Anderson and Fred S. McChesney, 168-94. Princeton: Princeton University Press, 2003.

Hall, Jerome. Theft, Law and Society. Boston: Little, Brown, and Company, 1935.

Harris, James. Ed. The Anatomy of Terror: Political Violence under Stalin. Oxford: Oxford University Press, 2013.

Harrison, Mark. "The Dictator and Defense." In Guns and Rubles: The Defense Industry in the Stalinist State, edited by Mark Harrison, 1-30. New Haven: Yale University Press, 2009. " "The Soviet Union after 1945: Economic Recovery and Political Repression," Past and Present, 210, Supplement 6, (2011): 103-120

Hazard, John. 'Soviet Property Law.' Cornell Law Quarterly, 30 (1945): 466-87.

Hay, Douglas. "Property, Authority and the Criminal Law." In Douglas Hay et al., Albion's Fatal Tree: Crime and Society in Eighteenth Century England, 17-63. Revised edition. London: Verso, 2011.

."Crime and Justice in Eighteenth- and Nineteenth-Century England." Crime and Justice, 2 (1980): 45-84

. "War, Dearth and Theft in the Eighteenth Century: The Record of the English Courts." Past and Present, 95 (1982): 117-160

. “Time, Inequality and Law's Violence.” In Law's Violence, edited by Austin Sarat and Thomas R. Kearns. Michigan: University of Michigan Press, 1992. 
Heinzen, James. The Art of the Bribe: Corruption, Politics, and Everyday Life under Stalin, 19411953. New Haven: Yale University Press, forthcoming.

"Informers and the State under Late Stalinism: Informant Networks and Crimes against 'Socialist Property'." Kritika: Explorations in Russian and Eurasian History, 8, 4 (2007): 789815

Hessler, Julie. A Social History of Soviet Trade. Princeton: Princeton University Press, 2004.

Huskey, Eugene. "Vyshinskii, Krylenko, and the Shaping of the Soviet Legal Order." Slavic Review, 46, 3 (1987): 414-428

Jones, William C. “Theft in the Qing Code.” American Journal of Comparative Law, 30, 3 (1982): 499-521

Khaustov, V.N., V.P. Naumov, and N.S. Plotnikova, eds., Lubianka: Stalin i VChK-GPU-OGPUNKVD. Ianvar' 1922-dekabr' 1936. Moscow: Materik, 2003.

Khlevniuk, O.V. et al., eds., Stalin i Kaganovich. Perepiska. 1931-1936 gg. Moscow: Rosspen, 2001.

Khlevniuk, O.V. Khoziain: Stalin i utverzhdenie stalinskoi diktatury. Moscow: Rosspen, 2010. . The History of the Gulag: From Collectivization to the Great Terror. New Haven: Yale University Press, 2004. . "The Objectives of the Great Terror, 1937-1938," in J.M Cooper, Maureen Perrie and E. A. Rees, eds., Soviet History, 1917-1953: Essays in Honour of R.W. Davies. New York: St Martin's, 1995.

Kondrashin, Viktor. Golod 1932-1933 godov: Tragediia Rossiiskoi derevni. Moscow: Rosspen, 2008.

Kokurin, A.I., and N.V. Petrov, eds., GULAG: Glavnoe upravlenie lagerei. 1917-1960. Moscow: Materik, 2000.

Kornai, Janos. The Socialist System: The Political Economy of Socialism. Oxford: Oxford University Press, 1992.

Kommunisticheskaia Partiia Sovetskogo Soiuza v rezoliutsiiakh i resheniiakh sezdov, konferentsii i plenumov Tsk. $9^{\text {th }}$ ed., vol.8. Moscow: Gospolitizdat, 1985.

Levi, Margaret. Of Rule and Revenue. Los Angeles: University of California Press, 1988.

Lewin, Moshe. “Taking Grain': Soviet policies of Agricultural Procurements before the War.” In Moshe Lewin, The Making of the Soviet System, 142-77. London: Methuen, 1985.

Libecap, Gary D. Contracting for Property Rights. Cambridge: Cambridge University Press, 1989.

Merrill, Thomas W., and Henry E. Smith. "What Happened to Property in Law and Economics?" Yale Law Journal, 111, 2 (2001): 357-398

Myerson, Roger B. "The Autocrat's Credibility Problem and Foundations of the Constitutional State." American Political Science Review, 102, 1 (2008): 125-139

North, Douglass C., and Robert Paul Thomas. The Rise of the Western World: A New Economic History. Cambridge: Cambridge University Press, 1973.

North, Douglass C. Institutions, Institutional Change and Economic Performance. Cambridge: Cambridge University Press, 1990.

"Ob okhrane imushchestva gosudarstvennykh predpriatii, kolkhozov i kooperatsii i ukreplenii obschestvennoi (sotsialisticheskoi) sobstvennosti” Sobranie zakonov SSSR, 1932, no. 62, Article 360 .

"Ob ugolovnoi otsvetstvennosti za khischenie gosudarstvennogo i obschestvennogo imuschestva." Vedomosti verkhovnogo soveta SSSR, 1947, no.19.

"Ob usilenii okhrany lichnoi sobstvennosti grazhdan." Vedomosti verkhovnogo soveta SSSR, 1947, no. 19 .

Olson, Mancur. "The Hidden Path to a Successful Economy." In The Emergence of Market Economies in Eastern Europe, edited by Christopher Clague and Gordon C. Rausser, 55-75. Oxford: Blackwell, 1992.

. "Dictatorship, Democracy, and Development." American Political Science Review, 87, 3 (1993): 567-576.

. Power and Prosperity: Outgrowing Communist and Capitalist Dictatorships. New York: Basic Books, 2000.

Packer, Herbert. The Limits of the Criminal Sanction. Stanford: Stanford University Press, 1968.

Poe, Steven C., and C. Neal Tate. "Repression of Human Rights to Personal Integrity in the 1980s: A Global Analysis." American Political Science Review 88, 4 (1994): 853-872 
Poznanski, Kazimierz Z. "A Property Rights Perspective on the Evolution of Communist-Type Economies.” In Constructing Capitalism, edited by Kazimierz Z. Poznanski, 71-96. Oxford: Westview, 1992.

Rakhunov, R. "Sovetskoe pravosudie i ego rol' v ukreplenii zakonnosti." Kommunist, no.7 (1956): $42-51$.

Riker, William H., and David L.Weimer. "The Economic and Political Liberalization of Socialism: The Fundamental Problem of Property Rights." Social Philosophy and Policy, 10, 2 (1993): 79102

Schull, Joseph. "What is Ideology? Theoretical Problems and Lessons from Soviet-Type Societies." Political Studies, 40 (1992): 728-741

Sergeeva, T.L. Ugolovno-pravovaia okhrana sotsialisticheskoi sobstvennosti v SSSR. Moscow: Akademia Nauk, 1954.

Shearer, David R. Policing Stalin's Socialism: Repression and Social Order in the Soviet Union, 1924-1953. New Haven: Yale University Press, 2009.

Solomon, Peter H. Jr. Soviet Criminal Justice under Stalin. Cambridge: Cambridge University Press, 1996.

Stalin, J.V. Works. Vols. 8 and 13. Moscow: Foreign Languages Publishing House, 1955.

Svolik, Milan W. The Politics of Authoritarian Rule. Cambridge: Cambridge University Press, 2012.

"Ukreplenie sotsialisticheskoi zakonnosti i iuridicheskaia nauka." [Editorial] Kommunist no.11, 1956: 12-23.

Umbeck, John. "Might Makes Rights: A Theory of the Formation and Initial Distribution of Property Rights." Economic Inquiry, 19 (1981): 38-59.

"Usilit' bor' bu s khischeniiami gosudarstvennoi, obschestvennoi in lichnoi sobstvennosti." [Editorial] Sotsialisticheskaia zakonnost' no.8 (1947): 1-4.

Utevskii, B.S., and Z.A. Vyshinskaia, Praktika primeneniia zakonodatel'stva po bor'be s khischeniiami sotsialisticheskogo imushchestva. Moscow: Gosiurizdat, 1954.

Vert, Nikolia [Nicolas Werth], and S.V. Mironenko, eds., Massovye repressii v SSSR, vol.1 of Istoriia stalinskogo gulaga: konets 20-kh-pervaia polovina 50-kh godov. Moscow: Rosspen, 2004.

Vert, Nikolia [Nicolas Werth]. Terror i besporiadok: Stalinism kak sistema. Moscow: Rosspen, 2010.

Viola, Lynne. The Unknown Gulag: The Lost World of Stalin's Special Settlements. New York: Oxford University Press, 2007.

Wintrobe, Ronald. The Political Economy of Dictatorship. Cambridge: Cambridge University Press, 1998.

Zelenin, I.E. “'Zakon o piati koloskakh': razrabotka i osuschestvlenie,” Voprosy istorii, no.1 (1998): 114-23

Zima, V.F. Golod v SSSR 1946-1947 godov: Proiskhozhdenie i posledstviia. Moscow: RAN, 1996.

Zubkova, E.Iu., et al., eds. Sovetskaia zhizn’ 1945-1953. Moscow: Rosspen, 2003. 


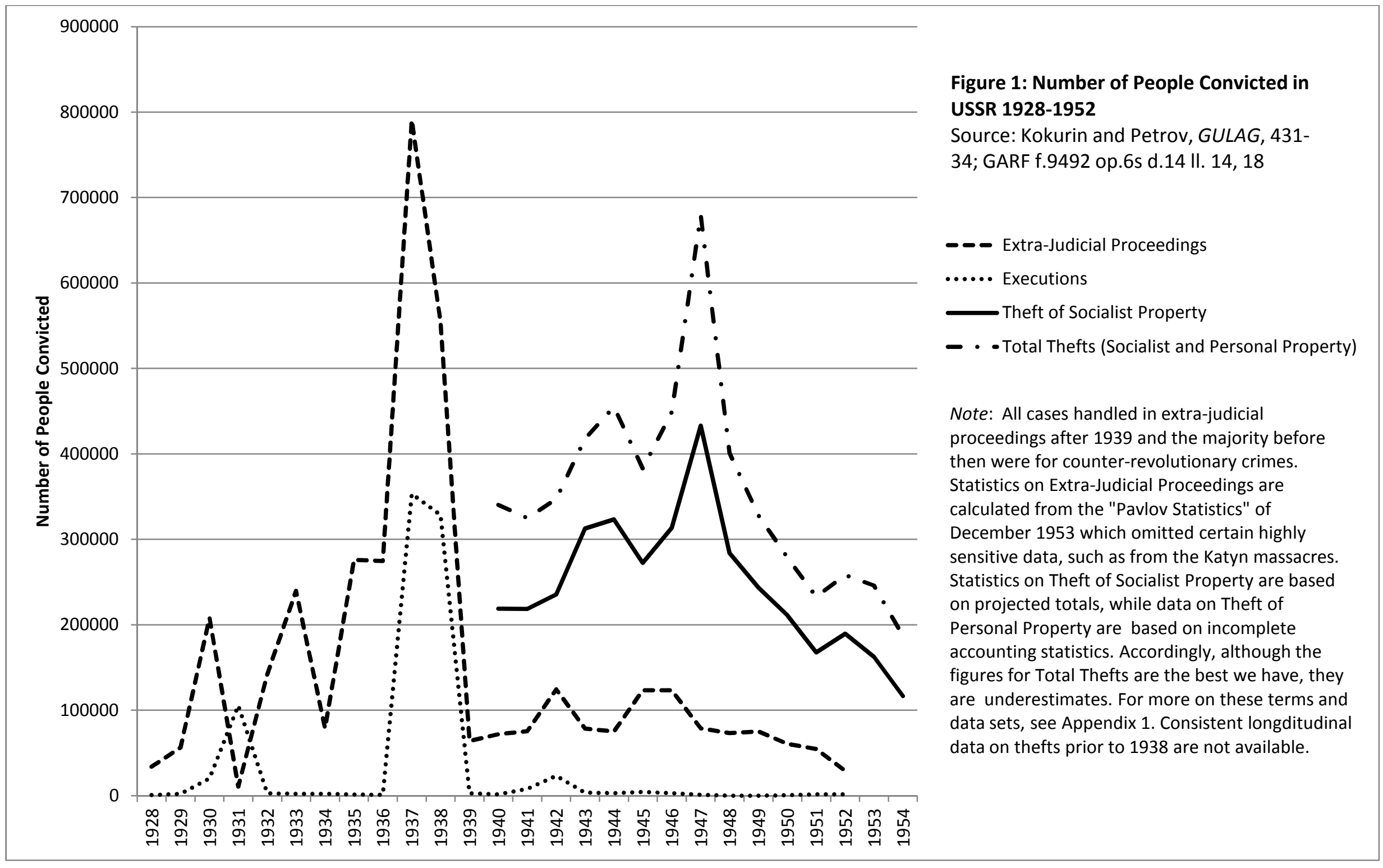




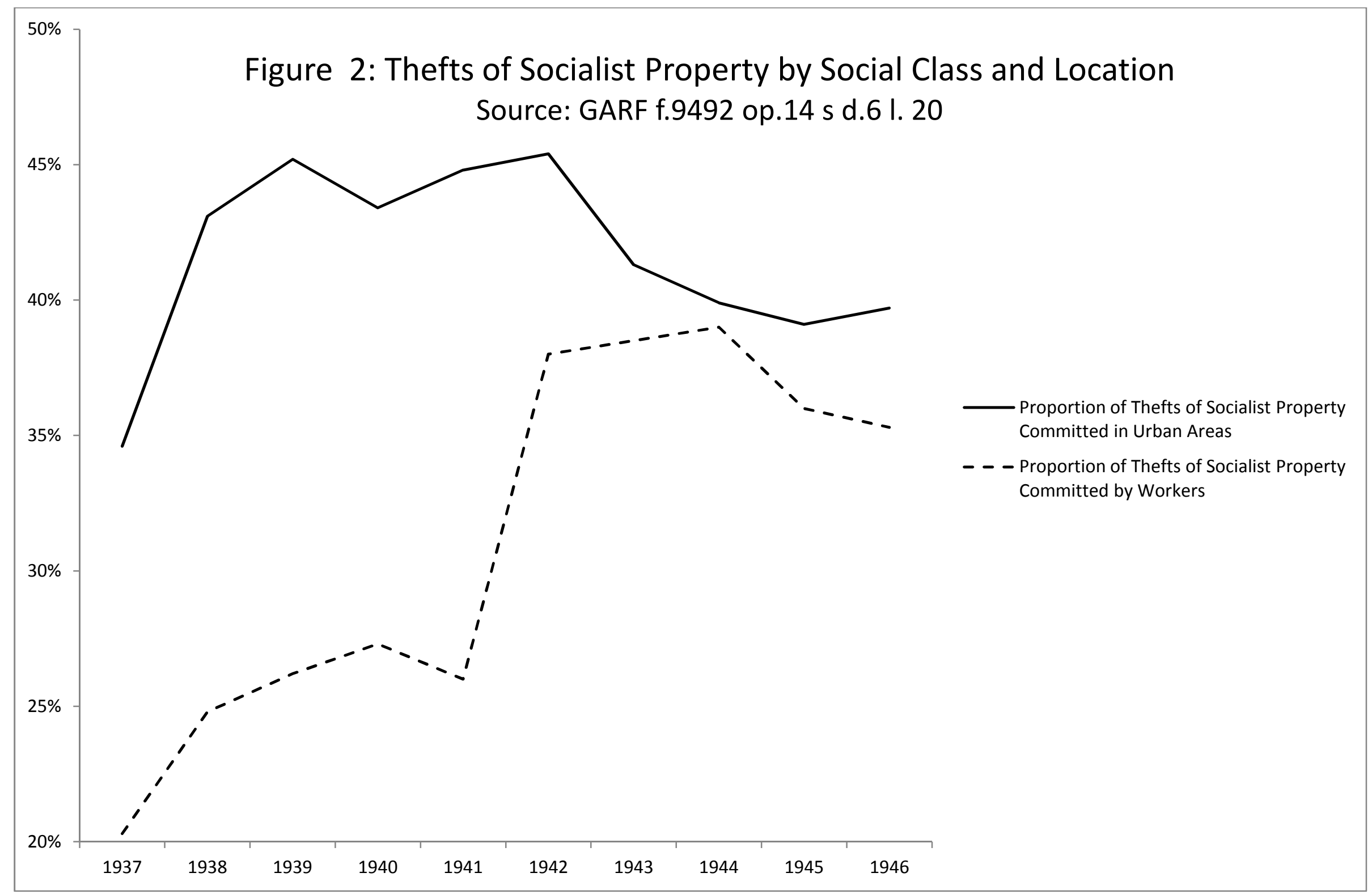




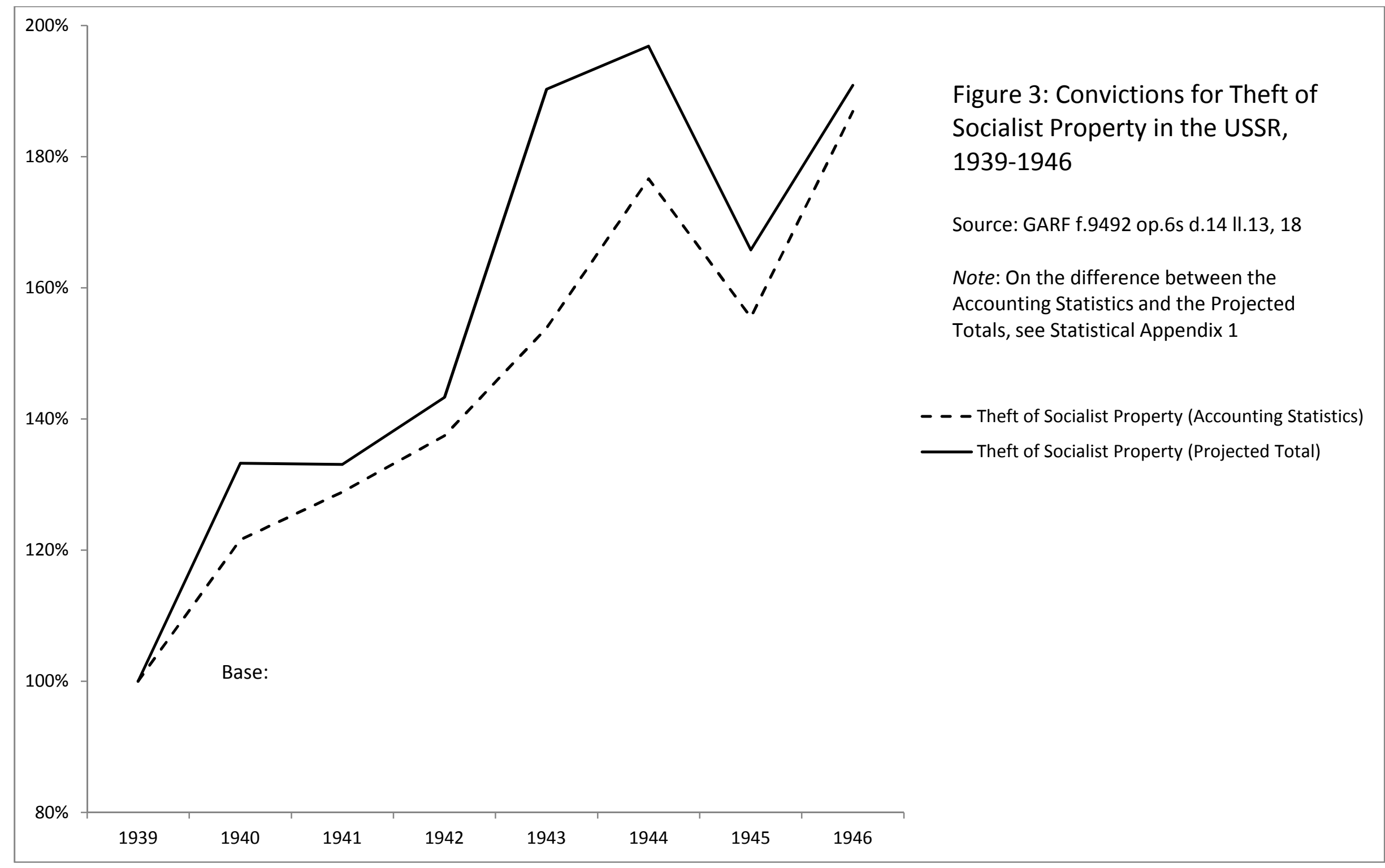




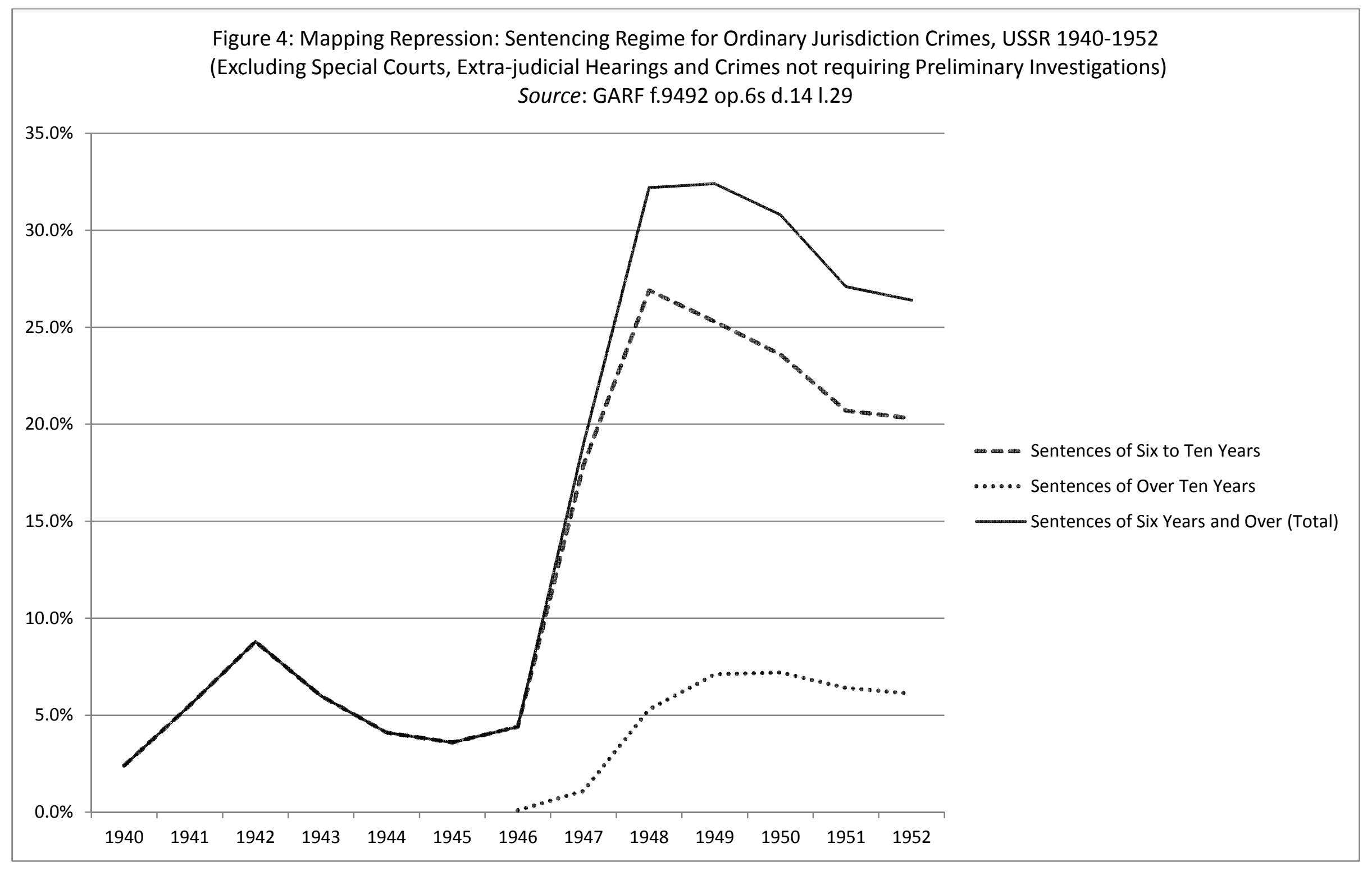




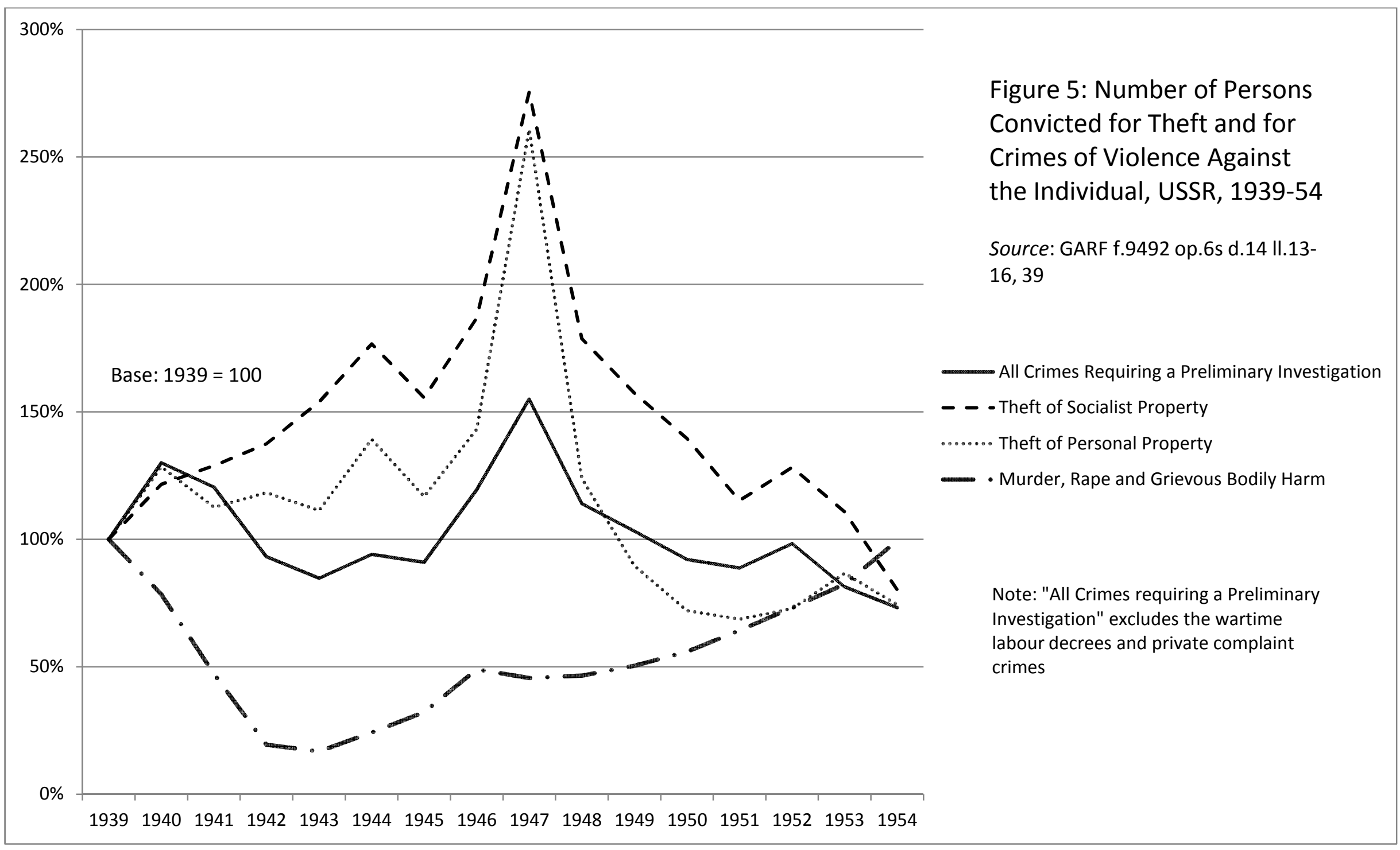




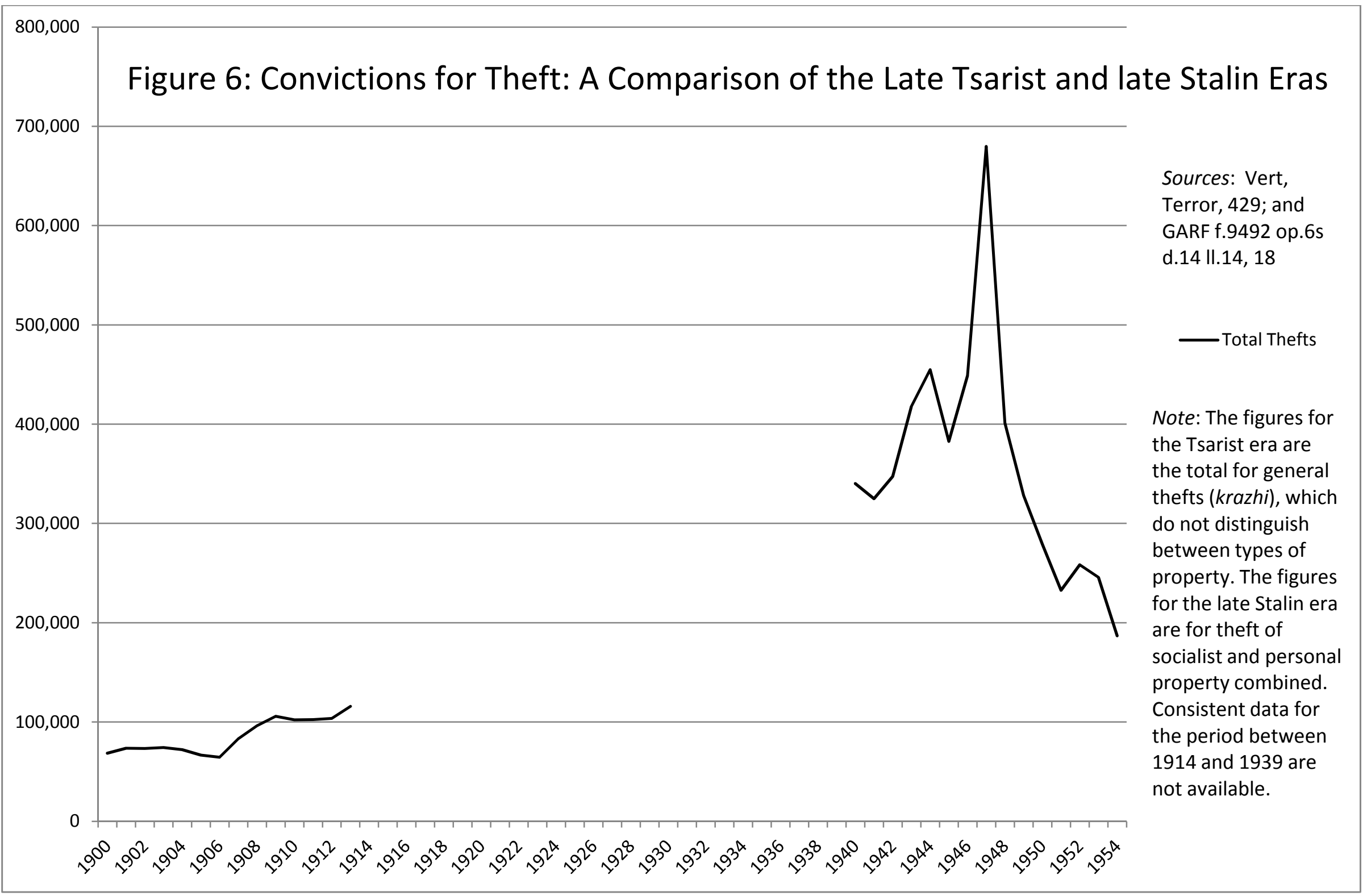




\section{Statistical Appendix}

The most authoritative statistics on convictions for theft of socialist property under the June 1947 decree were compiled by the statistical department of the USSR Supreme Court at various points in the mid-1950s. I have used the final version of these, which were presented on 21 January 1958 . The Supreme Court compiled two main sets of statistics on the theft decrees. The first were the accounting or reporting statistics (otchetnye dannye) which were submitted directly by the courts and which provided a full breakdown of convictions on a number of criteria such as sex, location, previous convictions, age and party membership. The otchetnye dannye are also important because they provide data on levels and types of punishment -in effect, on the forms of "repression." The second form of statistics were the projected totals (dannye s popravkoi na nepolnotu ucheta) which were estimates for the USSR as a whole and included figures for territories which, for one reason or another, were unable to submit the accounting statistics. As the Figure for the Statistical Appendix shows, the greatest divergence between the accounting statistics and the projected totals was during the war, when the authorities had to estimate numbers for those territories taken over by axis forces and when some courts' statistical offices lost staff to the front. Although they provide estimates of total convictions, the projected statistics do not disaggregate data on theft convictions by categories. Thus, although they are incomplete, for data on the social composition of offenders, the geographical location of thefts, and on punishment regimes, I have had to rely on the otchetnye dannye. The Figure also shows how, with the conclusion of the war, as more and more territories were re-integrated into the Soviet system of administration, the gap between the accounting statistics and the projected totals narrowed. The main source for the reporting statistics can be found in GARF f.9492 op.6s d.14 II.13, 20; and for the projected totals in ibid, I.18. Two further caveats that should be noted with regard to the accounting statistics. First they refer to general jurisdiction courts and do not include either military tribunals or the line (i.e. camp and transport) courts. However, a full run of aggregate annual statistics for socialist theft cases heard at military 
tribunals is available. With the exception of 1942 , when they reached 31,652 , the volume of cases dropped to around 20,000 for most of the mid-1940s and never exceeded $8 \%$ of the otchetnye dannye totals. While we do not have a run of statistics on theft cases in the line courts, we do have the figures for one year-1949-when they came to $6.4 \%$ of the total. On this see GARF f.5446 op.86a d.8073 II.5, 12; and Vert and Mironenko, Massovye repressii, 618. We should note, secondly, that there are two sets of statistics which are out of line with the totals calculated by the Supreme Court (even if we include the figures from the military tribunals and the line courts). The first appear in a letter from Gorshenin to Stalin in 1950, in which he gave figures for theft of socialist property of $378,000,508,000,275,000$ and 234,000 for the years 1946 to 1949 , which are considerably higher even than the projected totals. Later, Gorshenin gave a figure of 187,000 for 1952 . The second appear in a report by I Babukhin of December 1955. A composite of socialist and personal theft cases, Babukhin's totals again exceed the Supreme Court's figures. It is not clear how either Gorshenin or Babukhin's figures were compiled and neither is disaggregated in any way, so that apart from other concerns we may have as to how they were put together, they suffer from similar difficulties of application as the Supreme Court's projected totals. GARF f.5446 op.86a d.8073 I.12; and Vert and Mironenko, Massovye repressii, 592, 601, 604, 611. 


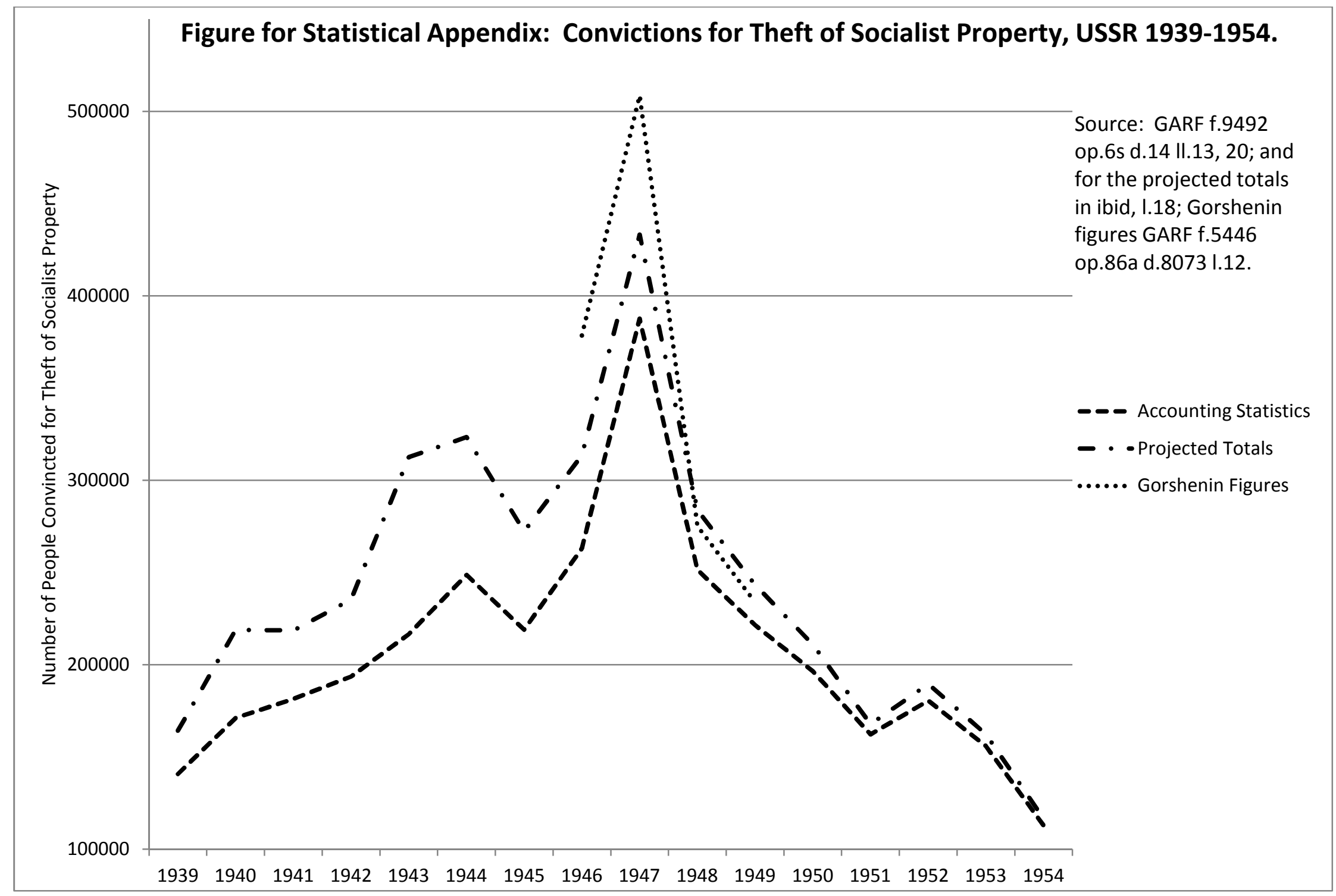

